\title{
Constraints on the late Ediacaran sulfur cycle from carbonate associated sulfate
}

Rosalie Tostevin ${ }^{1}$, Tianchen $\mathrm{He}^{1}$, Alexandra V Turchyn ${ }^{2}$, Rachel A Wood ${ }^{3}$, Amelia M Penny $^{3}$, Fred Bowyer ${ }^{3}$, Gilad Antler ${ }^{2}$, Graham A Shields ${ }^{1}$

${ }^{1}$ Department of Earth Sciences, University College London, Gower Street, London, WC1E6BT, UK

${ }^{2}$ Department of Earth Sciences, University of Cambridge, Downing Street, Cambridge, CB23EQ, UK

${ }^{3}$ School of Geosciences, University of Edinburgh, James Hutton Road, Edinburgh, EH93FE, UK

*Correspondence to Rosalie Tostevin: rosalie.tostevin@earth.ox.ac.uk

\section{Keywords: Sulfur isotopes; Neoproterozoic; Ediacaran; Superheavy pyrite; Method Development; Carbonate-associated sulfate}

\begin{abstract}
We report new sulfur isotope compositions $\left(\delta^{34} \mathrm{~S}\right)$ in carbonate associated sulfate (CAS) and pyrite from the lower Nama Group, Namibia ( $\sim 550$ to $<547 \mathrm{Ma}$ ), and use these data to interrogate terminal Ediacaran sulfur cycle dynamics. Our extraction method utilizes an improved pre-leaching procedure that reduces the likelihood of contamination from matrix-bound sulfur. Data generated with the improved extraction method show CAS $\delta^{34} \mathrm{~S}$ as much as $12 \%$ higher $\left({ }^{34} \mathrm{~S}\right.$-enriched) than previously reported which suggests a reevaluation of the phenomenon of
\end{abstract}


'superheavy' pyrite. Seawater sulfate $\delta^{34} \mathrm{~S}$ increases from 30 to $38 \%$ in the lower Nama Group, and we correlate this rise in $\delta^{34} S$ among contemporaneous marine basins. Global seawater sulfate $\delta^{34} \mathrm{~S}>35 \%$ is highly unusual in Earth history, and in the terminal Ediacaran is best explained by a high pyrite burial flux. Pyrite in the Nama Group is close in isotopic composition to coeval sulfate, but the sulfur isotope fractionation between sulfate and pyrite varies widely among different studied basins, suggesting highly heterogeneous redox and depositional conditions. 


\section{Introduction}

The hypothesized oxygenation, or ventilation, of the oceans during the Neoproterozoic is of considerable interest because it coincides with the rise of complex animal life (Canfield et al., 2007; Knoll and Sperling, 2014; Runnegar, 1982; Towe, 1970). However, the precise timing and mechanism for this oxygenation, and any causal relationship with animal evolution, remains controversial (Butterfield, 2009; X. Chen et al., 2015; Och and Shields-Zhou, 2012; Sperling et al., 2015). Two of the key fluxes that control the concentration of sulfate in the ocean - riverine sulfate derived from pyrite oxidation, and microbial reduction of sulfate to sulfide - depend indirectly on oxygen concentrations in the atmosphere and oceans, respectively. Furthermore, pyrite burial represents an important source of oxygen to the atmosphere over long timescales (Berner, 1989). Therefore, the biogeochemical sulfur cycle may have been significantly impacted by Neoproterozoic oxygenation. Although higher sulfate concentrations might be expected to correlate with increased oxygen availability, the sulfate concentration of the Neoproterozoic ocean remains unresolved (Fike and Grotzinger, 2008; Loyd et al., 2012; Moles et al., 2015).

The sulfur isotope composition of marine sulfate, $\delta^{34} \mathrm{~S}$ sw, tracks changes in the sources and sinks within the biogeochemical sulfur cycle (Claypool et al., 1980). The $\delta^{34} \mathrm{Ssw}$ has varied over Earth history as a result of changes in the riverine sulfate flux, the sulfur isotope composition of the riverine sulfate $\left(\delta^{34} S_{\text {riv }}\right)$, the sulfur isotope composition of pyrite $\left(\delta^{34} \mathrm{~S}_{\mathrm{pyr}}\right)$ and the amount of pyrite buried (Berner, 1989; 
Claypool et al., 1980; Garrels and Lerman, 1981). Of these various fluxes, the sulfur isotope composition of pyrite and the amount of pyrite buried remain both the largest lever on $\delta^{34}$ Ssw as well as the closest link to Earth's surface redox state. Sulfate is respired by sulfate reducing microbes in anoxic environments, producing sulfide which is enriched in ${ }^{32} \mathrm{~S}$ by up to $47 \%$ or possibly more (Canfield et al., 2010; Leavitt et al., 2013; Sim et al., 2011a, 2011b; Wortmann et al., 2001). In the modern ocean the $\delta^{34}$ Ssw is globally homogeneous $(21.1 \pm 0.8 \%$ o when measured via $\mathrm{SF}_{6}$; Johnston et al., 2014; Rees, 1978). $\delta^{34} \mathrm{~S}_{\mathrm{sw}}$ is elevated over riverine input (which is between 3 and $8 \%$, Canfield, 2013) because of the burial of ${ }^{32}$ S-enriched pyrite. Modern marine sulfate has a concentration of $28 \mathrm{mM}$, and a residence time of $10-20$ million years, which far exceeds the mixing time of the ocean (Paytan et al., 2004). At high sulfate concentrations, $\delta^{34} \mathrm{~S}$ sw should provide a globally integrated archive of the relative sources and sinks of sulfur to the global ocean. Marine sulfate concentrations, however, have likely varied widely through Earth history (Hardie, 1996). When the residence time of sulfate is reduced, the concentration and isotope composition of sulfate may vary within and among marine basins (Kah et al., 2004).

Reconstructing $\delta^{34} \mathrm{~S}$ sw through Earth history requires viable proxy minerals for marine sulfate. Barite $\left(\mathrm{BaSO}_{4}\right)$ produced in the open ocean provides a useful archive for the past $150 \mathrm{Ma}$ (the age of the oldest deep sea sediment cores) (e.g. Markovic et al., 2015; Paytan et al., 1998). Barite from the Neoproterozoic, deposited in seafloor exhalative events, has also been used to reconstruct seawater sulfate (Moles et al., 2015; Shields et al., 2007). Calcium sulfate minerals in evaporitic deposits are 
another viable proxy reservoir (Claypool et al., 1980; Strauss, 1997; Thode and Monster, 1965), and preserve seawater $\delta^{34}$ Ssw with minimal sulfur isotope fractionation (up to $+2.4 \%$, Raab \& Spiro 1991; Thode et al. 1961). However, evaporitic minerals commonly occur in restricted basins, can be subject to postdepositional fluid alteration, and suffer from poor chronological constraints (Bottrell and Newton, 2006). As the gypsum burial flux was limited during periods of low marine sulfate concentrations (Canfield 2004), there is a dearth of evaporite deposits in deep time. Trace sulfate in phosphorites has also been shown to preserve coeval $\delta^{34}$ Ssw under some circumstances (Hough et al. 2006; Shields et al. 1999; Shields et al. 2004), but phosphorite deposits are rare on a global scale.

'Carbonate associated sulfate' (CAS) is the most readily available and widely used proxy for seawater $\delta^{34}$ Ssw. CAS is thought to form when a sulfate ion replaces a carbonate ion in the calcium carbonate mineral structure, and sulfur isotopic fractionation during incorporation should be negligible (Staudt and Schoonen, 1995). Metastable carbonate minerals undergo recrystallization during diagenesis, and so may lose their associated sulfate, but original $\delta^{34}$ ScAS values are likely retained under most conditions (Gill et al., 2008; Kah et al., 2004; Lyons et al., 2004; Rennie and Turchyn, 2014; Staudt and Schoonen, 1995). The rate and extent of early diagenetic alteration is in part controlled by the sedimentation rate, the recrystallisation rate of unstable carbonate minerals, as well as the relative concentration of sulfate in the pore fluid versus the concentration in the carbonate minerals (Present et al., 2015; Rennie and Turchyn, 2014). 
Even if $\delta^{34} \mathrm{Ssw}$ is faithfully preserved in the carbonate record, there are concerns about the effective extraction of pristine marine phases and imparted contamination during cleaning and mineral extraction (Peng et al., 2014; Wotte et al., 2012). Carbonate samples selected for CAS-extraction may be pre-leached to remove matrix-bound contaminant sulfur, which may include atmospheric sulfate, organic sulfur, or disseminated pyrite, and these generally have a lower $\delta^{34} S$. Of these various contaminants, one major concern is the oxidation of reduced sulfur phases such as pyrite, as many studies use bleaches such as $\mathrm{NaOCl}$ and $\mathrm{H}_{2} \mathrm{O}_{2}$, which can act as effective oxidants (Marenco et al., 2008). It was recently suggested that secondary-atmospheric sulfate results in widespread contamination of $\delta^{34} S_{\text {CAS }}$, particularly in outcrop samples from arid or heavily polluted regions, as secondaryatmospheric sulfate forms a significant component of water leachable sulfates (Peng et al., 2014). Multiple pre-leaches in $10 \% \mathrm{NaCl}$ solution are now suggested for effective cleaning (Theiling and Coleman, 2015; Wotte et al., 2012), but the preleaching procedure is not yet standardized. Pre-leaching that is less thorough may not eliminate contaminants before the acid-leaching stage, resulting in acidleachable sulfate that does not represent primary $\delta^{34}$ Ssw.

Measurements of sulfate $\delta^{34} S$ may provide more interpretative power when paired with coeval pyrite $\delta^{34} \mathrm{~S}$, which preserves the $\delta^{34} \mathrm{~S}$ signature of the net reduced sulfur produced during microbial sulfate reduction. Sulfur isotope fractionation during microbial sulfate reduction, ${ }^{34} \varepsilon$ mic, depends largely on the rate of microbial sulfate 
reduction, which is impacted by other environmental factors, including temperature, sulfate concentration, the microbial community and organic carbon source (Bradley et al., 2015; Canfield, 2001; Canfield et al., 2010; Habicht and Canfield, 2001; Leavitt et al., 2013; Sim et al., 2011a, 2011b; Wortmann et al., 2001). Pyrite preserves the apparent sulfur isotope fractionation, $\Delta^{34} \mathrm{~S}_{\mathrm{sw}}$-pyr, which may differ from ${ }^{34} \varepsilon$ mic, and is controlled by sedimentary parameters including sedimentation rate, porosity, and the availability of reactive organic carbon and reactive iron oxides (Fike et al., 2015). Paired sulfate-pyrite sulfur isotope studies over the Proterozoic show step increases in $\Delta^{34} \mathrm{~S} s w$-pyr, which appear to relate closely to changes in the oxidation state of Earth's surface environment (Canfield, 1998; Fike et al., 2006). Existing $\delta^{34}$ Ssw records from the Neoproterozoic hint at an interesting evolution of the biogeochemical sulfur cycle towards the Ediacaran Cambrian boundary. A dramatic rise in $\delta^{34} S_{s w}$ in the latest Ediacaran strata $(<541$ Ma) has been documented from evaporites and CAS (Claypool et al., 1980; Fike and Grotzinger, 2008; Holser, 1977; Houghton, 1980; Solomon et al., 1971; Strauss et al., 2001). This increase has been interpreted as mixing with deep brines enriched in ${ }^{34}$ S through microbial sulfate reduction (Holser, 1977), or a rise in the fractional pyrite burial flux accompanied by increased weathering inputs with elevated $\delta^{34} S$ (Fike et al., 2006; Fike and Grotzinger, 2008). The comparatively discontinuous phosphorite record, however, does not show a similar increase in ${ }^{34} \mathrm{Ssw}_{\mathrm{sw}}$ (cf. Ediacaran data from Shields et al. 2004 and Cambrian data from Shields et al. 1999). 
The Nama Group, Namibia is a well-preserved terminal Ediacaran mixed clastic and carbonate succession, deposited between $\sim 550$ and 541 Ma (Grotzinger et al., 1995; Schmitz, 2012). Previous reports of $\delta^{34}$ Ssw from the Nama Group reveal an unexpected observation, whereby $\delta^{34} S_{\text {pyr }}$ is commonly higher than coeval $\delta^{34} \mathrm{~S}_{\mathrm{CAS}}$ (Ries et al., 2009). This result does not fit within the accepted frameworks for interpreting $\delta^{34} S$, as pyrite typically exhibits lower $\delta^{34} S$ compared with coeval sulfate. Sulfide oxidation produces oxidized sulfate that is depleted in ${ }^{34} \mathrm{~S}$ by $4-5 \% 0$ (abiotically - Fry et al. 1988), and <2\%o when microbially mediated (but see Kaplan \& Rittenberg 1964 for fractionations up to $18 \%$ ), which could in theory leave the residual sulfide pool 'heavy', but in most natural environments this signal would be overprinted by the larger sulfur isotope fractionation during microbial sulfate reduction (Canfield, 2001).

Here, we report high-resolution paired CAS-pyrite sulfur isotope data for the Kuibis Subgroup ( $\sim 550$ to $<547 \mathrm{Ma})$ of the Nama Group, from Zebra River, near Maltahoe, Hardap, Namibia. By applying improved methodologies that minimise the chance of contamination during the cleaning and leaching of carbonate, we produce an

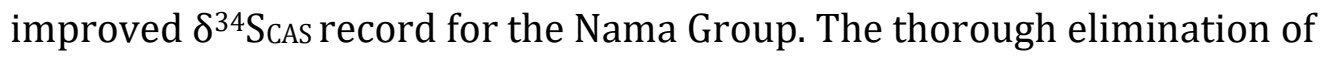
contaminants allows us to verify the presence of any 'superheavy' pyrite. We make a detailed comparison between the record from the Nama Group with recent sulfate and pyrite records from contemporaneous basins (Cui et al., 2016; Fike et al., 2006; Fike and Grotzinger, 2008), to assess global trends in the sulfur cycle, marine sulfate concentrations and variability in local redox and depositional conditions. 


\section{Geological and geochemical setting}

The Nama Group is a mixed carbonate-siliciclastic sequence deposited in a ramp system across two inter-connected sub-basins, the Witputs in the south and the Zaris in the north, separated by the Osis Arch (figure 1; Germs, 1974). The Nama Group hosts terminal Ediacaran fauna, including soft-bodied fossils belonging to the Ediacaran biota and the skeletal metazoans, Cloudina, Namacalathus and Namapoikia (Grant, 1990; Grotzinger et al., 2000; Hall et al., 2013; Macdonald et al., 2014; Penny et al., 2014, 2016; Wood et al., 2002). Trace fossils have been reported from the Omkyk member (Macdonald et al., 2014), consistent with the beginnings of infaunal bioturbation noted globally during this time (Mcllroy and Logan, 1999). Iron speciation data suggest that the Nama Group showed a heterogeneous redox landscape in shallow waters, more persistent oxygenation in most mid-ramp settings, and persistently anoxic and ferruginous in outer ramp waters (Wood et al., 2015).

Our section of the Nama Group, Zebra River Farm, spans the Kuibis Subgroup in the Zaris Basin, and includes the Omkyk and Hoogland Members. Zebra River is a distal inner ramp section, hosting laterally extensive microbial reef systems, and associated skeletal fossils, $<35 \mathrm{~mm}$ (Grotzinger et al., 2000). Iron speciation data suggest that Zebra River was persistently well-oxygenated, with some restricted anoxic ferruginous periods (Wood et al., 2015). An ash bed in the lowermost Hoogland Member of the Kuibis Subgroup provides robust U-Pb zircon age constraints $548.8 \pm 1 \mathrm{Ma}$ (Grotzinger et al. 1995), revised to $547.36 \pm 0.31$ Ma by 
Bowring et al. (2007). The base of the Nama Group is diachronous and has not been well dated, but the age is probably between 548 and $553 \mathrm{Ma}$, younging towards the Osis Arch (Germs, 1974; Ries et al., 2009). Therefore, the Kuibis Subgroup spans 1-6 Myrs and extends to $<547 \mathrm{Ma}$ at the top of the Hoogland member. The inner ramp position of Zebra River means that it may be a relatively late (i.e. young) part of the lower Nama Group.

Previously published carbonate $\delta^{13} \mathrm{C}$ values from the Nama Group reach as low as $7.4 \%$ and are interpreted to capture the tail end of the Shuram-Wonoka anomaly (Kaufman et al., 1991; Wood et al., 2015), a large and enigmatic negative carbon isotope excursion recorded globally in Ediacaran carbonates (Burns and Matter, 1993; Calver, 2000; Corsetti and Kaufman, 2003; Lu et al., 2013; McFadden et al., 2008; Saylor et al., 1998). The onset of the carbon isotope excursion is poorly constrained but likely post-dates the Gaskiers glaciation at 580 Ma (Macdonald et al., 2013). The Shuram anomaly had ended by 551 Ma in South China (Condon et al., 2005). Therefore, the duration of the Shuram event is unknown and could range from 5 to 50 Myrs (Le Guerroué, 2010). The recovery to positive $\delta^{13} \mathrm{C}$ is likely captured in the southern Witputs Basin (Wood et al., 2015). Elsewhere, the zenith of the negative carbon isotope excursion reaches $-12 \%$, below the $\delta^{13} \mathrm{C}$ of mantle carbon input, and so demands an exceptional explanation (Grotzinger et al., 2011).

It has been suggested that the Shuram carbon isotope anomaly results from oxidation of a large pool of reduced carbon supplying a substantial amount of ${ }^{12} \mathrm{C}$ to 
the ocean-atmosphere system; this pool of reduced carbon has been suggested to be either methane hydrates (Bjerrum and Canfield, 2011) or dissolved organic carbon (Rothman et al., 2003). This oxidation would, in theory, require a large amount of oxidant, and as such, the $\delta^{13} \mathrm{C}$ recovery to positive values is interpreted to represent the consumption of the pool of reductant and thus would be expected to be followed by an oxygenation event (Bjerrum and Canfield, 2011; Fike et al., 2006; McFadden et al., 2008; Rothman et al., 2003). One criticism of these models is that they have not considered the massive electron imbalance necessary to sustain the carbon isotope imbalance observed globally for many millions of years, leading others to suggest that the carbon isotope excursion is driven by meteoric or late stage burial diagenesis (Derry, 2010; Knauth and Kennedy, 2009; Swart and Kennedy, 2012). However, these mechanisms are inherently local and cannot explain the globally correlative negative excursion, and recent work has demonstrated that the isotopic signature was present at the time of deposition (Husson et al., 2015). An alternative explanation is global increase in the burial of authigenic carbonate, but this still requires a connection between preserved $\delta^{13} \mathrm{C}$ and the global DIC reservoir (Schrag et al., 2013).

\section{Methods}

Carbonate samples spanning the Omkyk and Hoogland members of the Kuibis Subgroup were trimmed to remove weathered edges and visible veins. Carbonate rock was crushed and then powdered using an agate mill. The CAS extraction method was developed by Tianchen He at University College London, and is an 
extension / combination of existing methods (best to give citations here). Approximately 8-10 g of powder was immersed in $10 \% \mathrm{NaCl}$ solution for five 24 hour leaches under constant agitation, and leachates were rinsed three times in 18 $\mathrm{M} \Omega \mathrm{cm}$ deionised water between each leach. After each leach, the presence of sulfate released during leaching was tested by adding saturated barium chloride solution $\left(\mathrm{BaCl}_{2}\right)$ to precipitate barite. No barite precipitate was observed after the third leach. Barite from three $\mathrm{NaCl}$ pre-leaches was retained and isotopically analysed. The carbonate, once cleaned, was then dissolved in $6 \mathrm{M} \mathrm{HCl}$ for $<20 \mathrm{~min}$. Time exposed to the acid was limited to ensure minimal pyrite oxidation. Acid-leachable sulfate was collected as barite by adding a saturated $\mathrm{BaCl}_{2}$ solution. Filtrates were cleaned 4 times in ultrapure water and dried before analysis.

Acid volatile sulfur (AVS) and iron sulfide minerals, including pyrite, were chemically extracted using $\mathrm{HCl}$ and chromous chloride distillation, respectively, at the University of Leeds. The gas generated during distillation was bubbled through silver nitrate solution to precipitate $\mathrm{Ag}_{2} \mathrm{~S}$ (Canfield et al., 1986; Wood et al., 2015). Where sufficient precipitate formed, both AVS and sulfide mineral fractions were retained for analysis. The barite from CAS extraction and silver sulfide from pyrite extraction were weighed into tin cups with an excess of vanadium pentoxide for sulfur isotope analysis at the University of Cambridge. Samples were combusted in a Flash EA coupled through continuous flow through a magnesium perchlorate trap and gas chromatograph before the gas was introduced to a Delta-Advantage mass spectrometer. $\delta^{34} \mathrm{~S}$ is reported versus the Vienna Canon Diablo Troilite (VCDT) 
standard. Isotopic barite standards (NBS 127) had an average standard deviation of $0.18 \%$ o $(1 \sigma) . \delta^{34} \mathrm{~S}$ values were corrected for machine drift using this bracketing standard NBS $127(20.3 \%)$

The same samples were dissolved in $2 \%$ nitric acid, and analysed for major element concentrations ( $\mathrm{Ca}, \mathrm{Mg}, \mathrm{Fe}, \mathrm{Mn}$ and $\mathrm{Sr}$ ) using an inductively coupled plasma optical emission spectrometer (ICP-OES) at the Cross-Faculty Elemental Analysis Facility, University College London (see supplementary data file). The concentration of CAS was measured in an aliquout of the filtered acid-leachates, prior to $\mathrm{BaCl}_{2}$ addition, via ICP-OES. Wavelength 182.5 was selected to avoid interference with calcium ions, and analysis was conducted using the polyboost function. 


\section{Results}

We present $\delta^{34}$ ScAs from 51 carbonate samples spanning the Omkyk and Hoogland members of the Kuibis Subgroup from the Nama Group, Namibia. The average $\delta^{34} \mathrm{~S}_{\mathrm{CAS}}$ for each member and the standard deviations around the mean are given in table 1. The concentration of $S_{C A S}$ and $S_{p y r}$ in these samples is low, averaging 68.7 ppm (range: 32.6 - 166.6 ppm) and 9.3 ppm (range: <2 - 49.7 ppm), respectively. There is a steady increase in average $\delta^{34}$ Scas throughout the section (figure 2). The lower Omkyk member averages $30.1 \pm 5.1 \%$ (range: 21.9 - 39.3\%o). The upper Omkyk member averages $32.3 \pm 3.8 \%$ (range: 26.3 - 39.9\%o). The lower Hoogland member averages $36.4 \pm 4.5 \%$ (range: $27.2-41.4 \%$ ) and the upper Hoogland member averages $38.9 \pm 4.1 \%$ (range: $29.7-45.4 \%$ ).

Sulfur isotope data for pre-leach solutions, measured on the first two leaches for three samples, show lower $\delta^{34} \mathrm{~S}_{\mathrm{NaCl}}$ compared with coeval $\delta^{34} \mathrm{~S}_{\mathrm{CAS}}$ (by as much as 15.8\%o) (table 2). This suggests that leaching in $\mathrm{NaCl}$ has removed contaminant sulfur, that if unremoved would lower the apparent $\delta^{34}$ ScAs value. The final three pre-leaches did not result in sufficient $\mathrm{BaSO}_{4}$ precipitate for sulfur isotope analysis, suggesting contaminant sulfur was removed effectively within the first two preleaches. The analysed samples from Zebra River show evidence for high-quality preservation, including relatively high $\delta^{18} 0$ (89\% of samples $>-10 \%$ ), low $\mathrm{Mn} / \mathrm{Sr}$ ratios ( $97 \%$ of samples $<1)$, and high strontium concentrations $(294-5802 \mathrm{ppm}$; with an average of $1509 \pm 986 \mathrm{ppm} ; 40 \%$ of samples $>1500 \mathrm{ppm}$, Wood et al., 2015). 
There is no significant covariation between $\delta^{34} \mathrm{~S}_{\mathrm{CAS}}$ and strontium concentrations, $\mathrm{Mn} / \mathrm{Sr}$ ratios, total organic carbon or total iron (see supplementary data file). We also find that there is no co-variation between $\delta^{34}$ S CAS and cerium or yttrium anomalies measured on the same samples (Tostevin et al., 2016).

We present $\delta^{34} S_{\text {pyr }}$ for 11 samples. Pyrite concentrations are low and chromium reduction for many carbonate samples did not produce sufficient pyrite for subsequent sulfur isotope analysis. In the lower Omkyk member, the average $\delta^{34} S_{\text {pyr }}$ is $36.3 \pm 1.8 \%$ o $(\mathrm{n}=5)$, in the upper Omkyk member $\delta^{34} \mathrm{~S}_{\text {pyr }}$ averages $31.7 \pm 2.2 \%$ o $(n=3)$, and the Hoogland member $\delta^{34} S_{\text {pyr }}$ averages $40.4 \pm 1.5 \%$ o $(n=3) . \quad \delta^{34} S_{p y r}$ measured on one AVS extraction produced one lower $\delta^{34} \mathrm{~S}_{\text {AvS }}(26.7 \%)$ value. The

\section{Discussion}

\subsection{Diagenetic overprinting}

Our $\delta^{34} \mathrm{~S}_{\mathrm{CAS}}$ data come from well-described marine sections and have $\delta^{13} \mathrm{C}$ that can be correlated regionally and globally (Fike et al., 2006; Ries et al., 2009; Wood et al., 2015). Normal marine rare earth element patterns with superchondritic yttrium anomalies throughout the Nama Group further support the interpretation that this section was deposited under open marine conditions (Tostevin et al., 2016). ${ }^{34}{ }^{3}$ CAS shows no correlation with various geochemical indicators of diagenesis, including the concentration of sulfate in the carbonate lattice, $\mathrm{Mn} / \mathrm{Sr}$ or $\delta^{18} \mathrm{O}_{\text {сасоз }}$ (figure 3), indicating that late-stage diagenetic alteration by non-marine fluids was not the primary controls on $\delta^{34}$ ScAs. However, these traditional parameters for evaluating 
diagenesis may not be sufficient to identify syndepositional or early diagenetic alteration in CAS.

We observe sample-to-sample fluctuations from 0.1 to $12.1 \%$ o (average $4.6 \%$ ), which are too large to be explained by analytical error or fluctuations in the marine reservoir. Different components of complex carbonate rocks may be differently affected by diagenesis, and so some of the stratigraphic variability in $\delta^{34}$ ScAs may result from facies changes and the leaching of different carbonate components (Present et al., 2015). However, our $\delta^{34} \mathcal{S}_{\mathrm{CAs}}$ do not appear to correlate with facies or lithology (figure 3). Early diagenetic overprinting, or the incorporation of sulfate into the carbonate lattice during burial and recrystallization, can increase $\delta^{34} \mathrm{~S}_{\mathrm{CAS}}$, due to microbial sulfate reduction, which through Rayleigh fractionation enriches the pore fluid sulfate in the heavier ${ }^{34} \mathrm{~S}$ isotope. It is also possible for early diagenesis to decrease $\delta^{34} S_{\text {CAS }}$, if recrystallisation or the precipitation of new carbonate minerals occurs close to the chemocline where oxidising fluids interact with sulfide.

Results from modern sediments show that diagenetic alteration of $\delta^{34} \mathrm{~S}_{\mathrm{CAS}}$ is more extensive where high carbonate recrystallization rates intersect with the uppermost zone of sulfate reduction (Rennie and Turchyn, 2014). Pore fluid $\delta^{34}$ S evolves to higher values throughout the zone of sulfate reduction while the rate of carbonate recrystallization decreases with age. At rapid sedimentation rates, carbonate recrystallization will occur deeper in the sediment pile, where pore water sulfate 
concentrations are low and therefore little isotopically altered sulfate will be incorporated into the carbonate lattice. At slow sedimentation rates, carbonate will undergo intense recrystallization before the onset of sulfate reduction and evolution of pore fluid $\delta^{34} S$ so the sulfate incorporated into the carbonate lattice will be minimally evolved from seawater. $\delta^{34} \mathrm{~S}_{\mathrm{CAS}}$ is most vulnerable to resetting at intermediate sedimentation rates, where recrystallization occurs in the presence of sulfate rich, yet isotopically distilled pore fluids (Rennie and Turchyn, 2014). Under modern conditions, diagenesis is unlikely to result in increases in $\delta^{34} S_{\text {CAS }}$ greater than 4\%o (Rennie and Turchyn, 2014). However, in the Ediacaran, a number of conditions may have enabled greater alteration of $\delta^{34}$ SAAs.

CAS concentrations are exceptionally low in the Nama Group, both compared with modern and Neoproterozoic carbonate rocks from other sections (Gellatly and Lyons, 2005; Staudt and Schoonen, 1995; Strauss et al., 2001). This may be a reflection of the reduced contribution from non-CAS sulfate, due to improved cleaning procedures. Alternately, the low CAS concentrations may result from diagenetic loss, but may also indicate low initial CAS concentrations as a result of a small seawater sulfate reservoir (Berelson et al., 2008; Busenberg and Niel Plummer, 1985; Gill et al., 2008; Marenco et al., 2008). These low concentrations of CAS could increase vulnerability to diagenetic overprinting. However, if sulfate concentrations were very low, this may have reduced the likelihood of large sulfur isotope fractionations associated with microbial sulfate reduction (Algeo et al., 2015; Habicht et al., 2002), and this would prevent pore water sulfate from evolving 
dramatically away from seawater values. However, we note that large fractionations are still possible at very low sulfate conditions (Canfield et al., 2010; Crowe et al., 2014; Knossow et al., 2015; Weber et al., 2016). Further, sulfate concentrations in pore waters beneath a low-sulfate-concentration water column would also be low, limiting the amount of pore fluid sulfate that could be incorporated during diagenetic recrystallization.

The Nama Group was likely originally aragonite or high Mg calcite, based on original skeletal mineralogies (Zhuravlev and Wood, 2008), modelling trends (Hardie, 2003) and fluid inclusion data (Brennan et al., 2004), and so will have undergone extensive recrystallisation. The partitioning of sulfur between pore water and carbonate may be different for aragonite and calcite, and any isotope fractionation associated with mineralogical transformations is unconstrained. The zone of sulfate reduction may have been shallower in sediments underlying low oxygen waters where there was no penetrative bioturbation. However, the accumulation rate of thrombolitestromatolite carbonate reef systems may have been very rapid compared to modern carbonate platforms, while the sedimentation rate in the Nama Group overall appears to be exceptionally high at 50-300 $\mathrm{mMyr}^{-1}$ based on a minimum and maximum age range. Taken together, these differences in Precambrian seawater chemistry and sedimentation patterns, mean that the upper limit for diagenetic alteration is unknown for the Nama Group, but could have differed significantly from the $4 \%$ limit based on a model derived for modern sediments (Rennie and 
Turchyn, 2014). We conclude that diagenetic alteration likely explains most of the large sample-to-sample fluctuations in $\delta^{34} \mathrm{~S}_{\text {CAS. }}$.

SAS, a common contaminant in CAS studies, can accumulate on outer surfaces and microcracks within outcrops, particularly in arid regions such as southern Namibia, and this SAS may be removed by effective cleaning (Peng et al., 2014). However, if SAS or sulfate in meteoric waters derived from pyrite oxidation is incorporated into secondary carbonate in micro-veins that are impossible to identify and exclude during the powdering process, the contaminant signal would not be affected by preleaching and would be included in the acid leachable sulfate fraction. This, along with variable early diagenetic alteration, may explain the scatter in our $\delta^{34} \mathrm{~S}_{\mathrm{CAS}}$ data.

$\delta^{34} S_{\text {pyr }}$ reflects the sulfur isotope composition of hydrogen sulfide produced during microbial sulfate reduction, or other microbially mediated reactions and depends largely on local depositional conditions (e.g. sulfate concentration, iron availability, sulfate reduction rate and sedimentation rates) (Canfield 2001; Kaplan \& Rittenberg 1964). Unlike $\delta^{34}$ Ssw, which should be globally homogeneous, $\delta^{34} S_{\text {pyr }}$ shows a wide range of isotope compositions reflecting these local depositional conditions. Some pyrite in the Nama Group may have been transformed to iron oxides and aqueous sulfate during oxidative weathering (Wood et al., 2015). While this process may reduce pyrite concentrations, it should not impact the residual $\delta^{34} S_{\text {pyr }}$ (Balci et al., 2007). $\delta^{34} S_{\text {pyr }}$ from bulk rock analyses may include late-stage sulfide minerals 
formed during migration of sulfide-bearing fluids through strata rich in reactive iron.

\subsection{Laboratory extraction of CAS}

Organic sulfur, the products of oxidative pyrite weathering and secondary atmospheric sulfate (SAS) must all be removed before carbonates are dissolved with acid to extract CAS. Previous studies have suggested that the sulfur extracted during pre-leaching can be as much as $24 \%$ lower in $\delta^{34}$ S than primary CAS (Peng et al., 2014). Cleaning in water has been shown to be inadequate for removing this contaminant matrix-bound sulfur (Peng et al. 2014; Wotte et al. 2012). We have taken care to minimise the possibility of contamination during the extraction of CAS from our samples. We pre-leached five times in $10 \% \mathrm{NaCl}$ solution under constant agitation, with three rinses in ultrapure water in between each $\mathrm{NaCl}$ leach. We used small amounts of powder (8-10 g) in enclosed vessels to minimise any possibility of contamination from within the laboratory. Prior studies on similar sections cleaned large amounts of powder ( $\sim 300 \mathrm{~g})$ once with Milli-Q water for $24 \mathrm{~h}$ before acid leaching, which was common in earlier CAS studies (e.g. Fike et al., 2006; Fike and Grotzinger, 2008; Ries et al., 2009; Zhang et al., 2004, 2003).

We present average $\delta^{34}$ SCAS $12.4 \%$ higher than equivalent samples reported in Ries et al. (2009) for the lower Omkyk member. Disseminated sulfide minerals must have been present in the original rock in concentrations equivalent to or higher than those extracted. Since the $\delta^{34} \mathrm{~S}$ of this pyrite is generally close to $\delta^{34} \mathrm{SCAS}$, the ${ }^{32} \mathrm{~S}$ 
enriched contaminant sulfur extracted during the pre-leaching stage of CAS extraction likely comes from the products of pyrite weathering mixed with other sources (e.g. SAS). This would explain the lower sulfur isotope composition of the pre-leaches (up to $16 \%$ lower than resultant CAS, table 2), and in cases where this sulfate is not effectively removed during pre-leaching, would contribute to the lower measured CAS sulfur isotope composition.

Our average $\delta^{34} S_{\text {CAS }}$ is consistent with Ries et al. (2009) for the upper Omkyk and Hoogland members, but with overall lower standard deviations (table 1). The scatter in their $\delta^{34} S_{\text {cas }}$ may partly result from differing contributions from contaminant phases. There remains significant scatter in our data, however, which is common in CAS data, but it is unclear whether this represents varying degrees of incorporation of non-CAS sulfur, CAS from secondary carbonate phases, or early diagenetic overprinting of $\delta^{34} S_{\text {CAS }}$ (Bottrell and Newton, 2006; Kampschulte and Strauss, 2004; Rennie and Turchyn, 2014; Turchyn et al., 2009).

\section{3 'Superheavy' pyrite}

There have been several studies investigating the $\delta^{34} \mathrm{~S}$ in various late Neoproterozoic sedimentary successions that report pyrite enriched in ${ }^{34} \mathrm{~S}$ relative to the global average for seawater sulfate at that time, which is also ${ }^{34} \mathrm{~S}$-enriched relative to other times in the Proterozoic or Phanerozoic (Bottomley et al., 1992; Liu et al., 2006; Shen et al., 2008; Strauss et al., 1992). This 'superheavy' pyrite has also been observed a few times in the Phanerozoic and modern environments, but the 
$\delta^{34} S_{\text {pyr }}$ is only slightly elevated compared with $\delta^{34} S_{\text {CAS }}$ (Aller et al., 2010; Ferrini et al., 2010; Goodfellow and Jonasson, 1984). On the whole, the occurrence of 'superheavy' pyrite involves a small number of anomalously ${ }^{34} \mathrm{~S}$ enriched samples within a larger $\delta^{34} S_{p y r}$ data set, which in some cases are not reported alongside coeval $\delta^{34} S_{\text {CAS }}$ (e.g. Bottomley et al. 2009, $\mathrm{n}=1$; Shen et al. 2008, $\mathrm{n}=4$ ). In particular, Ries et al. (2009) report some extremely ${ }^{34}$ S-enriched pyrite in the Hoogland member ( 9 samples $>45.0 \%$, reaching $80.2 \%$ ), but we do not reproduce these in our more limited pyrite data set. Although our highest reported $\delta^{34} \mathrm{~S}_{\mathrm{CAS}}$ is $45.4 \%$, Ries et al. (2009) report some extremely enriched $\delta^{34} \mathrm{~S}_{\mathrm{CAS}}$, up to $64.2 \%$, from the same part of the stratigraphy as the 'superheavy' pyrite.

An apparent 'superheavy' pyrite effect may also result from normal marine $\delta^{34} S_{p y r}$, in the presence of $\delta^{34} \mathrm{~S}_{\mathrm{CAS}}$ that is low compared with contemporaneous local or global sections as a result of contamination during CAS extraction. Our average ${ }^{34} \mathrm{~S}_{\mathrm{CAS}}$ is $12.4 \%$ o higher than equivalent samples reported in Ries et al. (2009) for the lower Omkyk member. Significantly, the lower Omkyk member is one section of the Nama Group where Ries et al. (2009) describe the phenomenon of 'superheavy' pyrite (highlighted by the grey box in figure 2). We have not sampled the exact same section as Ries et al. (2009), and so lateral variability in pyrite sulfur isotope composition or $\delta^{34}$ CAS across the basin remains a possible explanation (Hurtgen et al., 2006).

Pyrite $\delta^{34}$ S remains higher than $\delta^{34} \mathrm{~S}_{\text {CAS }}$ for two samples in the lower Omkyk member and this could point to the presence of genuine 'superheavy' pyrite; 
diagenetic alteration of $\delta^{34}$ S CAS to lower values, or that small amounts of contaminant sulfur remain even after extensive cleaning. In general, our new CAS dataset suggests that 'superheavy' pyrite may not be as widespread in the Nama Group as previously thought, and that where it does occur, the offset between seawater sulfate and pyrite $\delta^{34} S$ may be smaller and therefore easier to explain (Ries et al. 2009).

While some of the offset reported in Ries et al. (2009) could have arisen from artifacts during CAS extraction, there remains some extraordinarily high $\delta^{34} S_{p y r}$ in the Nama Group that needs to be addressed. 'Superheavy' pyrite has been attributed to decoupling of surface and bottom water sulfur reservoirs in a stratified ocean, where bottom waters produce enriched $\delta^{34} S_{\text {pyr }}$ via Rayleigh distillation, and surface waters record undistilled $\delta^{34}$ ScAs (Liu et al., 2006). This model cannot explain observations in the Nama Group, because there is sedimentological evidence for storm driven mixing in parts of the basin, and iron speciation data suggests there are no sulfidic bottom waters (Ries et al., 2009; Wood et al., 2015). Ries et al. (2009) suggest that under low sulfate conditions, small sulfur isotope fractionations during sulfide oxidation could deplete $\delta^{34} \mathrm{~S}_{\mathrm{sw}}$ in ${ }^{34} \mathrm{~S}$ relative to $\delta^{34} \mathrm{~S}_{\mathrm{pyr}}$ via Rayleigh-type distillation within pore waters. This interpretation requires minimal sulfur isotope fractionation during microbial sulfate reduction, which may be achieved through low sulfate concentrations or evolution of sulfide $\delta^{34} S$ towards parent sulfate in closed systems. If pore water sulfide is partially re-oxidised, aided by storm-driven reworking or bioturbation beneath aerobic bottom waters, the residual sulfide pool 
may be left heavy compared with seawater sulfate. Pyrite generally forms within the sediments and so reflects pore water chemistry, whereas carbonate forms close to the sediment-water interface in contact with the marine sulfate reservoir (Gomes and Hurtgen, 2013). $\delta^{34} \mathrm{~S}_{\text {CAS }}$ therefore forms in different environments to $\delta^{34} \mathrm{~S}_{\mathrm{pyr}}$, decoupling $\Delta^{34} \mathrm{~S}_{\text {sw-pyr }}$ from ${ }^{34} \varepsilon_{\text {mic. }}$. Within the Zebra River section, previous work has identified a spectrum of fully anoxic (ferruginous), low oxygen (manganous) and well-oxygenated bottom waters (Tostevin et al., 2016; Wood et al., 2015). We note that our $\delta^{34}$ SAS and $\delta^{34}$ pyr show no clear correspondence to inferred local bottom water redox conditions. The presence of superheavy pyrite may indicate shallow, high energy depositional environments rather than low concentrations of seawater sulfate (Fike et al., 2015). Regardless of the exact mechanism, simple models struggle to explain extremely high $\delta^{34} S_{\text {pyr }}(>50 \% 0)$, wide ranges in $\delta^{34} S_{\text {pyr, }}$, and the absence of complementary low $\delta^{34} S_{\text {pyr, }}$ and so the genesis of 'superheavy' pyrite remains enigmatic (Aller et al., 2010; Ferrini et al., 2010; Fike et al., 2015).

\subsection{The terminal Ediacaran Sulfur cycle}

Phanerozoic ocean chemistry is dominated by long-term cycles of alternate calciumrich and magnesium-sulfate-rich seawater (Hardie, 2003, 1996). It is unclear if these trends existed in the Precambrian, but if so, the Ediacaran is projected to be a sulfate-rich 'aragonite' sea (Hardie, 2003). The aragonite and high-Mg calcite original mineralogy of the earliest skeletal metazoans supports this assumption, at least for the final 10 Myrs of the Ediacaran, as well as fluid inclusion data (Brennan et al., 2004; Zhuravlev and Wood, 2008). Superimposed on these potential cyclic 
trends in the major ion chemistry of the ocean is the hypothesized Neoproterozoic Oxygenation Event, during which higher atmospheric $\mathrm{O}_{2}$ together with higher rates of physical erosion may have increased sulfate delivery flux, while sinks for reduced sulfur within the ocean did not rise apace. Constraining the concentration of sulfate in the ocean in the past, however, is challenging and controversial (Algeo et al., 2015; Fike et al., 2006; Kah et al., 2004; Loyd et al., 2012).

There are several lines of evidence from previous studies suggesting that marine sulfate concentrations at this time were relatively high. For example, there is evidence that lagoonal waters inside rimmed ocean margins were sulfidic, but not sulfate-limited in South China (Li et al., 2010; Och et al., 2016; Wang et al., 2012). $\delta^{34} S$ in some barite deposits appears to be invariant, supporting higher marine sulfate reservoirs (Moles et al., 2015), but the origin of this barite is not demonstrably marine. Limited data from fluid inclusions in evaporite minerals are consistent with high marine sulfate concentrations, although quantifying sulfate concentrations from fluid inclusions involves large errors and an assumption about the calcium concentration, while the data originate from evaporites that formed in restricted basins (Brennan et al., 2004; Kovalevych et al., 2006). Evaporite deposits are known worldwide from the Ediacaran, including deposits in Oman, India, Russia and Pakistan (Houghton, 1980; Kovalevych et al., 2006; Mattes and Morris, 1990; Strauss et al., 2001). Although the distribution of evaporites through time is predominantly driven by tectonics, the presence of anhydrite in these deposits, where demonstrably marine, requires relatively high sulfate concentrations (several 
$\mathrm{mM}$ ) within the Ediacaran-Cambrian transition interval. A rise in $\Delta^{34} \mathrm{~S}_{\mathrm{sw}}$-pyr during the Neoproterozoic was traditionally interpreted to record a shift towards sulfate reduction combined with sulfur disproportionation in a relatively oxidising environment (Canfield, 1998; Fike et al., 2006). These multiple lines of evidence for high marine sulfate concentrations are contradicted by recent data showing low $\Delta^{34} \mathrm{~S}$ sw-pyr and rapid rates of change in sulfur isotope composition of proxy minerals, which instead suggest that sulfate concentrations remained low throughout the Neoproterozoic (Algeo et al., 2015; Loyd et al., 2012; Ries et al., 2009). However, reconstructing sulfate concentrations from trends in $\delta^{34} S$ requires multiple assumptions, and diagenetic alteration of $\delta^{34} \mathrm{~S}_{\mathrm{CAS}}$ can result in gross underestimates of the marine sulfate reservoir.

\subsubsection{Pyrite formation}

Sulfur isotopic fractionation during microbial sulfate reduction $\left({ }^{34} \varepsilon\right.$ mic) is largely associated with intracellular enzymes, but sulfur isotope fractionation may also accompany sulfate transport across the membrane (Rees, 1973). ${ }^{34} \varepsilon$ mic is a function of the cell specific sulfate reduction rate, which is in itself dependent on sulfate concentration, along with other environmental parameters (Canfield, 2001; Habicht et al., 2005, 2002; Habicht and Canfield, 2001; Leavitt et al., 2013; Sim et al., 2011a). More recent work has suggested that large sulfur isotope fractionation can be found with sulfate concentrations as low as $30 \mu \mathrm{M}$, confounding the simple relationship between the magnitude of fractionation and the size of the marine sulfate reservoir (Canfield et al., 2010; Crowe et al., 2014; Knossow et al., 2015; Weber et al., 2016). 
Physiological factors also are important in determining the expressed sulfur isotope fractionation in any given microbial community (Bradley et al., 2015). Larger ${ }^{34} \varepsilon$ mic may be expressed in mixed communities in natural environments, where sulfur undergoes disproportionation and complex recycling, although large sulfur isotope fractionations have also been recorded during sulfate reduction in pure culture (Sim et al., 2011a). The largest sulfur isotope fractionations would be expected close to the chemocline, where oxidation and disproportionation should (in theory) be most prevalent, but the fractionation has been observed to decrease at redox interfaces in modern environments (Canfield and Teske, 1996; Fike et al., 2009, 2008; Wilbanks et al., 2014), so the importance of disproportionation in natural environments is unclear. In addition, temperature and the carbon source can affect ${ }^{34} \varepsilon_{\text {mic }}$ although deconvolving whether they impact ${ }^{34} \varepsilon_{\text {mic }}$ or whether they just impact the overall rate of microbial sulfate reduction is problematic (Canfield 2001; Detmers et al. 2001; Sim et al. 2011).

The broad rise in $\Delta^{34}$ Ssw-pyr through the Neoproterozoic could record a switch towards oxidation and disproportionation, or a rise in marine sulfate concentrations, both of which would reflect marine oxygenation, but controls on $\Delta^{34}$ Ssw-pyr are complex and other changes in the marine environment and biosphere could also have impacted $\Delta^{34} S_{s w-p y r}$ (Canfield, 1998; Fike et al., 2006). The expansion of eukaryotes around $800 \mathrm{Ma}$ (Knoll, 2014), and the diversification of animal life 580-520 Ma, and more aerobic water column conditions would have relegated more complex organic carbon molecules to sediments (those which would 
have escaped oxic respiration), which may have slowed sulfate reduction rates, increasing ${ }^{34} \mathcal{E}$ mic (Canfield, 2001; Detmers et al., 2001; Sim et al., 2011b).

Furthermore preserved $\Delta^{34} \mathrm{~S}_{\mathrm{sw}}$-pyr may differ considerably from ${ }^{34} \mathcal{E}_{\text {mic }}$ under certain sedimentation patterns (Fike et al., 2015). Under open system conditions, where pore waters remain in contact with sulfate rich seawater, only a small fraction of the sulfate pool is converted to sulfide during microbial sulfate reduction, and so sulfate concentrations remain high and large ${ }^{34} \mathcal{E}$ mic are possible. Under closed system conditions, where pore waters are isolated from seawater, or where MSR occurs in a sulfate-poor water column, the sulfate pool may be nearly quantitatively converted to sulfide, and as a result the sulfur isotopes are conserved and the preserved $\Delta^{34} \mathrm{Ssw}_{\mathrm{spr}}$ is much smaller (Gomes and Hurtgen, 2013). In summary, the general rise in $\Delta^{34} \mathrm{~S}$ sw-pyr across the Neoproterozoic does not necessarily have a straightforward relationship with oxygenation and the appearance of oxidation and disproportionation or rising sulfate concentrations and may represent a change in organic carbon or other sedimentary dynamics.

Despite the general trend of increasing $\Delta^{34} \mathrm{~S}$ sw-pyr through the Nafun Group in Oman, in both the overlying Ara Group and the Dengying Formation in South China, local $\Delta^{34}$ Ssw-pyr appears to decrease from $50 \% 0$ to $30 \%$ o coincident with the first appearance of Cloudina (Cui et al., 2016; Fike and Grotzinger, 2008; Sahoo et al., 2016). This transition to smaller $\Delta^{34} \mathrm{~S}_{\mathrm{sw}}$-pyr in younger strata may mark the retreat of the zone of sulfate reduction into the sediments, and the onset of more closed system behaviour (Gomes and Hurtgen, 2013). Alternately, the drop in sulfur 
isotope fractionation could suggest a switch to microbial sulfate reductiondominated systems with little reoxidation or subsequent disproportionation, indicating a return to less oxidising conditions (Canfield and Teske, 1996; Canfield and Thamdrup, 1994; Cui et al., 2016; Fike and Grotzinger, 2008; Sahoo et al., 2016; Wu et al., 2015). Additional mechanisms to reduce $\Delta^{34} S_{s w}$-pyr include higher rates of sulfate reduction, possibly driven by changes in organic carbon availability, the position of the chemocline, lower sulfate concentrations or temperature (Bradley et al., 2015; Canfield et al., 2010; Canfield, 2001; Habicht and Canfield, 2001; Leavitt et al., 2013; Sim et al., 2011a, 2011b; Wortmann et al., 2001).

$\Delta^{34} \mathrm{~S}_{\mathrm{SW}}$-pyr in the Nama Group $(<6.6 \%$ ) is small compared with any of the sulfur isotope fractionations recorded in Oman and South China, and such small sulfur isotope fractionations may indicate a microbial-sulfate reduction dominated sulfur cycle in the presence of low sulfate concentrations, much higher rates of sulfate reduction locally, or depositonal conditions that promoted small preserved $\Delta^{34} \mathrm{~S}_{\mathrm{sw}}$ pyr. The contrasting $\Delta^{34}$ Ssw-pyr among basins could be a result of globally heterogeneous redox conditions in the late Ediacaran, supporting varying amounts of sulfide re-oxidation and disproportionation. Heterogeneous redox conditions are supported by differences in local redox proxies, such as Ce anomalies and Fespeciation, between the Nama Group and Oman and China (Ling et al., 2013; Och et al., 2016; Schröder and Grotzinger, 2007; Tostevin et al., 2016; Wang et al., 2012; Wood et al., 2015). Complex and localized controls on ${ }^{34} \varepsilon_{\text {mic }}$ and preserved $\Delta^{34}$ Sswpyr could also cause inter-basin heterogeneity. For example, the presence of Fe(II) in 
the water column in the Nama Group could have increased the efficiency of the pyrite sink, leading to bulk $\delta^{34} S_{\text {pyr }}$ that is close to $\delta^{34}$ Ssw. The Nama Group was deposited on a storm dominated carbonate ramp system, where intense reworking or high sedimentation rates may have affected the preserved $\Delta^{34} \mathrm{~S}_{\mathrm{sw}}$-pyr. The globally heterogeneous $\Delta^{34} \mathrm{~S}_{\mathrm{SW} \text {-pyr }}$ in the Ediacaran is a stark warning against too literal interpretation of $\delta^{34} S_{\text {pyr }}$ as a record of changes in the global sulfur cycle.

\subsubsection{The marine sulfate reservoir}

At high marine sulfate concentrations, $\delta^{34} \mathrm{~S}_{\mathrm{sw}}$ and sulfate concentrations should be globally homogeneous across long timescales ( $>1 \mathrm{Ma}$ ), as high concentrations imply large residence times. Rapid temporal changes in $\delta^{34} \mathrm{~S}$ sw are more likely when sulfate concentrations are lower, as there is more possibility for the $\delta^{34} \mathrm{~S}$ sw of marine sulfate to be impacted by local processes like river fluxes or to show interbasin heterogeneity. Using the present day flux of sulfur into and out of the ocean $\left(3 \times 10^{12}\right.$ molyr $\left.^{-1}\right)$, the calculated sulfate residence time drops below $\sim 100,000$ years when sulfate concentrations are less than $0.2 \mathrm{mM}$, and below $\sim 10,000$ years when sulfate concentrations are less than $0.02 \mathrm{mM}$. A residence time of 10,000 years may have been short enough to permit inter-basin heterogeneity depending on the mixing time of the various ocean basins in the late Ediacaran Period. However, much about this calculation is unconstrained; for example, the rate of input and output fluxes in the Ediacaran may have been dramatically different from today, with substantially lower oxidative weathering fluxes and higher pyrite burial fluxes. 
Rates of change in $\delta^{34} \mathrm{~S}$ sw are commonly used to estimate the size of the marine sulfate reservoir, assuming that faster rates of change represent a smaller marine sulfate reservoir that can be more easily perturbed over short timescales. However, this approach is limited by the inability of most models to account for variations in the $\delta^{34} S$ of the input or output fluxes. In these models, the average global isotope offset between sulfate and buried pyrite is often estimated from the recorded $\Delta^{34}$ Ssw-pyr in a given section, but $\Delta^{34}$ Ssw-pyr varies both temporally and spatially. Further, early diagenesis may alter $\delta^{34} S_{\text {CAS }}$ dramatically away from $\delta^{34} S_{s w}$, as would inclusion of contaminant sulfate in $\delta^{34} \mathrm{~S}_{\mathrm{CAS}}$ analysis. Inclusion of non-meaningful sample-to-sample fluctuations in rate models would lead to drastic underestimates of the size of the seawater sulfate reservoir. A more powerful approach may be to compare $\delta^{34}$ Sw records between marine basins, as $\delta^{34}$ Ssw should be globally homogeneous when sulfate concentrations are high. It is therefore important to determine if consistent sulfur isotope records are recorded in geographically separated basins.

The depositional age of the lower Nama Group is well constrained from U-Pb dates from ash beds within the Hoogland Member (547.3 \pm 0.3 Ma - Grotzinger et al. 1995; Schmitz 2012). A rise in $\delta^{34}$ Ssw is recorded in limited and poorly age-constrained data from evaporites in Siberia (Claypool et al., 1980), Iran (Houghton, 1980), India (Strauss et al., 2001) and Australia (Solomon et al., 1971). These data converge on $\delta^{34} \mathrm{~S}$ for seawater sulfate of 30 to $35 \%$ for the terminal Ediacaran, consistent with data presented here. The Ara Group in the Huqf Supergroup, Oman, can be 
correlated more precisely using carbon isotope chemostratigraphy and a U-Pb zircon date in the A0 member (546.7 $\pm 0.3 \mathrm{Ma}$; Bowring et al., 2007, Fike et al., 2006; Fike and Grotzinger, 2008; Mattes and Morris, 1990; Morris et al., 1990; Wu et al., 2015; figure 4). The depositional age of the Dengying Formation, South China, is less well constrained, but should be approximately contemporaneous with the Nama Group, based on the presence of Cloudina (globally distributed for 10 Myr), carbon isotope chemostratigraphy, detrital zircon ages (548 \pm 8 Ma; Cui et al., 2016; figure 4) and ID-TIMS U-Pb zircon ages for volcaniclastic ash beds ( $<551 \pm 0.7 \mathrm{Ma}$; Condon et al., 2005)

$\delta^{34} \mathrm{~S}_{\mathrm{CAS}}$ is high in the Kuibis Subgroup and shows a general rising trend from an average of $30 \%$ at the base towards an average of $38 \%$ at the top (figure 2). In Oman, a rapid positive $\delta^{34}$ Ssw excursion begins $\sim 547 \mathrm{Ma}$, rising from 30 to $42 \%$ o (Fike \& Grotzinger 2008; Wu et al. 2015), dubbed the Ara anomaly. Older parts of the section (the Buah Formation, $>547 \mathrm{Ma}$ ), however, record lower $\delta^{34} \mathrm{~S}_{\mathrm{CAS}}(20-$ 25\%o) compared with the Kuibis Subgroup (Fike et al., 2006). In the Dengying Formation, Zhang et al. (2004) report $\delta^{34}$ SCAS between $20-30 \%$, in contrast to Y. Chen et al., (2015), who report higher $\delta^{34} \mathrm{~S}_{\mathrm{CAS}}$ between $30-40 \%$. While these two studies are based on different geographic sections that may record independent $\delta^{34} \mathrm{~S} s w$, in the Zhang (2004) study, dolostone powders were not cleaned prior to acid dissolution, and we suggest that the reported $\delta^{34}$ ScAs may have been affected by inclusion of non-CAS sulfur. Therefore, the Dengying Formation records elevated $\delta^{34}$ Ssw consistent with the Nama Group (Y. Chen et al., 2015). This is further 
supported by high resolution $\delta^{34} S_{\text {CAS }}$ from the Gaojiashan member, in the lower half of the Dengying Formation (32 to 46\%o, Cui et al., 2016, figure 4).

Carbon isotope chemostratigraphy provides a potentially independent correlation framework to compare sulfur isotope records. A transition from negative to positive $\delta^{13} \mathrm{C}$ is recorded in the Buah Formation in Oman, apparently correlative with $\delta^{13} \mathrm{C}$ in the Nama Group (see TP2 and TP3 on figure 4). The Zebra River section reaches $2 \%$ at the base, but $\delta^{13} \mathrm{C}$ as low as $-7.4 \%$ are recorded in the directly underlying member in older parts of the Nama Group (e.g. Brak, see Wood et al., 2015). Using this correlation framework, the sulfur isotope records among the various published sections are clearly inconsistent. If the Nama Group and the Huqf Supergroup both represent open marine conditions, with consistent $\delta^{13} \mathrm{C}$, then the residence time of sulfate must have been very low, permitting spatial variability in $\delta^{34}$ Ssw between basins. One way to reduce the residence time of sulfate is for the sulfate reservoir to have been small, but sulfate concentrations are hypothesised to be high in the Huqf Supergroup, to explain the large recorded $\Delta^{34} \mathrm{~S}_{\mathrm{Sw}}$-pyr and fluid inclusion data from evaporites (Brennan et al., 2004; Fike et al., 2006). The formation of gypsum evaporite deposits is itself evidence for marine sulfate concentrations of at least several mM in the upper Ara Group. Alternately, the Huqf Supergroup may have been partially or fully isolated from the global ocean, with an independent $\delta^{34} S_{s w}$ that reflects local inputs or the unidirectional influx of seawater (Wu et al., 2015). However, there is convincing sedimentological evidence that the Ara evaporites are marine in nature (Schroder et al., 2004; Schröder et al., 2005, 2003), and a sustained 
connection with the global ocean may be required to explain the large volume of evaporite deposition.

Considering the radiometric age constraints, the $\delta^{34} \mathrm{~S}_{\mathrm{CAS}}$ records from Oman, China and Namibia could potentially be consistent. To reconcile the $\delta^{34} \mathrm{~S}_{\text {CAS }}$ records between the three sections requires that the lower Nama Group and the Dengying Formation are contemporaneous with the A0 member in the Ara Group (deposited between TP1 and TP 2 on figure 4). While the more negative $\delta^{13} \mathrm{C}$ recorded in parts of the Nama Group records the recovery from Shuram carbon isotope excursion, the base of the section is diachronous and the negative $\delta^{13} \mathrm{C}$ at the base of Zebra River section may only record the post-Shuram return to more stable conditions (TP1 and TP2 on figure 4). It is possible that the sulfur isotope records are consistent between Namibia and Oman, and this supports a rapid and global transition to high $\delta^{34} S$ following the termination of the Shuram carbon isotope excursion, as has been reported elsewhere (Fike and Grotzinger, 2008). We suggest that $\delta^{34}$ Ssw climbed from $\sim 20 \%$, close to modern marine sulfate $\delta^{34}$ S, to much higher $\delta^{34} \mathrm{~S}(\sim 40-45 \%$ o recorded in the Dengying Formation, the Ara Group and the Nama Group) some time before 547 Ma (Y. Chen et al., 2015; Cui et al., 2016; Fike et al., 2006; Fike and Grotzinger, 2008; Wu et al., 2015).

This rise in $\delta^{34} \mathrm{~S}_{\text {CAS }}$ occurred following the termination of the Shuram carbon isotope excursion, and the marine sulfate $\delta^{34} S$ in the terminal Ediacaran is exceptionally high compared with almost all other periods in Earth history (Claypool et al., 1980). 
One mechanism to generate high values for $\delta^{34} \mathrm{~S}_{\mathrm{CAS}}$ is an increase in $\Delta^{34} \mathrm{~S}_{\mathrm{sw}}$-pyr, burying more ${ }^{32} \mathrm{~S}$ enriched pyrite, leaving more ${ }^{34} \mathrm{~S}$ behind in the ocean. Large $\Delta^{34}$ Ssw-pyr could result from increased marine sulfate concentrations, enhanced delivery of more complex organic matter, or more oxidising conditions that support multi-stage disproportionation of reactive intermediates. $\Delta^{34} \mathrm{~S}_{\mathrm{Sw}}$-pyr varies widely among marine basins, but existing data do not support an increase in the average global $\Delta^{34} \mathrm{Ssw}$-pyr in the terminal Ediacaran; indeed most measured pyrite is isotopically higher than at other points in time, including in this study (Cui et al., 2016; Fike and Grotzinger, 2008, figure 4). Elevated $\delta^{34} S_{\text {CAS }}$ may instead have been driven by an increase in the pyrite burial flux, fpy. Mechanisms to increase fpy include high sedimentation rates, widespread water column anoxia, high delivery of iron or high rates of productivity. Increased weathering rates may have delivered nutrients, driving productivity and simultaneously promoting water column anoxia (Cui et al., 2016). This weathering flux may additionally have delivered alkalinity and cations that would have increased carbonate deposition, consistent with the very high carbonate accumulation rates recorded for the Nama Group (50-300 $\mathrm{mMyr}^{-1}$ ). Fike and Grotzinger, (2008) suggest that changes in the $\delta^{34} \mathrm{~S}$ and flux of pyrite burial alone cannot explain such elevated $\delta^{34} S_{s w}$, without the additional presence of elevated $\delta^{34} S_{\text {riv }}(>12 \% 0)$. One mechanism to elevate $\delta^{34} S_{\text {riv }}$ is the preferential weathering of sulfates, in the form of evaporite deposits, over sulfide minerals (Wu et al., 2015). We speculate that high sulfate delivery rates drove some anoxic basins transiently sulfidic, consistent with local sulfidic conditions reported for the terminal Ediacaran from China (Och et al., 2016; Wang et al., 2012). This 
sulfide could have titrated iron from the ocean, resulting in a pulse of pyrite burial, followed by an increase in oxidising power in the oceans.

\section{Conclusions}

We present 51 new $\delta^{34} S_{\text {CAS }}$ compositions from the lower Nama Group $(\sim 550-<547$ Ma), Namibia. Our data show higher $\delta^{34} \mathrm{~S}_{\text {CAS }}$ than previous studies, which we attribute to improved cleaning procedures and reduced contributions from contaminant sulfur. We suggest that the phenomenon of 'superheavy' pyrite, previously reported from these sections, may in part be an artifact of contamination due to inadequate cleaning procedures, and that true $\delta^{34} \mathrm{~S}_{\mathrm{sw}}$ is close to coeval $\delta^{34} \mathrm{Spyr}_{\mathrm{pr}}$. The Nama Group records elevated $\delta^{34}$ Ssw and shows a climbing trend from $30 \%$ to $38 \%$. This rise in $\delta^{34}$ Ssw appears to be recorded globally, suggesting a rapid transition in the sulfur cycle, possibly driven by changing redox conditions and an increase in the pyrite burial flux. The stark contrast in $\Delta^{34} \mathrm{~S}_{\mathrm{sw}}$-pyr recorded in different sections is consistent with heterogeneous redox or depositional conditions among Ediacaran basins.

\section{Acknowledgements}

RT, GAS and RAW acknowledge financial support from NERC's Life and the Planet project (NE/1005978/1) and support for isotope analyses came from ERC StG 307582 'CARBONSINK' to AVT. Thanks to Rob Newton for helpful discussions, and Yongbo Peng and David Fike for constructive reviews. Romain Guilbaud and Simon 
Poulton assisted with pyrite extractions. We are grateful to L. and G. Fourie for access to Zebra River farm, and Gerd Winterleitner for help with field work.

\section{References}

Algeo, T.J., Luo, G.M., Song, H.Y., Lyons, T.W., Canfield, D.E., 2015. Reconstruction of secular variation in seawater sulfate concentrations. Biogeosciences 12 , 2131-2151. doi:10.5194/bg-12-2131-2015

Aller, R.C., Madrid, V., Chistoserdov, A., Aller, J.Y., Heilbrun, C., 2010. Unsteady diagenetic processes and sulfur biogeochemistry in tropical deltaic muds: Implications for oceanic isotope cycles and the sedimentary record. Geochimica et Cosmochimica Acta 74, 4671-4692. doi:10.1016/j.gca.2010.05.008

Balci, N., Shanks III, W.C., Mayer, B., Mandernack, K.W., 2007. Oxygen and sulfur isotope systematics of sulfate produced by bacterial and abiotic oxidation of pyrite. Geochimica et Cosmochimica Acta 71, 3796-3811. doi:10.1016/j.gca.2007.04.017

Berelson, W., Corsetti, F., Johnson, B., Vo, T., Der, C., 2008. Carbonate-associated sulfate as a proxy for lake level fluctuations: a proof of concept for Walker Lake, Nevada. J Paleolimnol 42, 25-36. doi:10.1007/s10933-008-9245-z

Berner, R.A., 1989. Biogeochemical cycles of carbon and sulfur and their effect on atmospheric oxygen over phanerozoic time. Palaeogeography, Palaeoclimatology, Palaeoecology 75, 97-122. doi:10.1016/00310182(89)90186-7

Bjerrum, C.J., Canfield, D.E., 2011. Towards a quantitative understanding of the late Neoproterozoic carbon cycle. Proceedings of the National Academy of Sciences 108, 5542 -5547. doi:10.1073/pnas.1101755108

Bottomley, D.J., Veizer, J., Nielsen, H., Moczydlowska, M., 1992. Isotopic composition of disseminated sulfur in Precambrian sedimentary rocks. Geochimica et Cosmochimica Acta 56, 3311-3322.

Bottrell, S.H., Newton, R.J., 2006. Reconstruction of changes in global sulfur cycling from marine sulfate isotopes. Earth-Science Reviews 75, 59-83.

Bowring, S.A., Grotzinger, J.P., Condon, D.J., Ramezani, J., Newall, M.J., Allen, P.A., 2007. Geochronologic constraints on the chronostratigraphic framework of the Neoproterozoic Huqf Supergroup, Sultanate of Oman. Am J Sci 307, 10971145. doi:10.2475/10.2007.01

Bradley, A.S., Leavitt, W.D., Schmidt, M., Knoll, A.H., Girguis, P.R., Johnston, D.T., 2015. Patterns of sulfur isotope fractionation during Microbial Sulfate Reduction. Geobiology n/a-n/a. doi:10.1111/gbi.12149

Brennan, S.T., Lowenstein, T.K., Horita, J., 2004. Seawater chemistry and the advent of biocalcification. Geology 32, 473 -476. doi:10.1130/G20251.1

Burns, S.J., Matter, A., 1993. Carbon isotopic record of the latest Proterozoic from Oman. Eclogae Geologicae Helvetiae.

Busenberg, E., Niel Plummer, L., 1985. Kinetic and thermodynamic factors controlling the distribution of SO 32- and $\mathrm{Na}+$ in calcites and selected 
aragonites. Geochimica et Cosmochimica Acta 49, 713-725.

doi:10.1016/0016-7037(85)90166-8

Butterfield, N.J., 2009. Oxygen, animals and oceanic ventilation: an alternative view. Geobiology 7, 1-7. doi:10.1111/j.1472-4669.2009.00188.x

Calver, C.R., 2000. Isotope stratigraphy of the Ediacarian (Neoproterozoic III) of the Adelaide Rift Complex, Australia, and the overprint of water column stratification. Precambrian Research 100, 121-150.

Canfield, D.E., 2013. Sulfur isotopes in coal constrain the evolution of the Phanerozoic sulfur cycle. Proc. Natl. Acad. Sci. U.S.A. 110, 8443-8446. doi:10.1073/pnas.1306450110

Canfield, D.E., 2004. The evolution of the Earth surface sulfur reservoir. American Journal of Science 304, 839-861.

Canfield, D.E., 2001. Isotope fractionation by natural populations of sulfate-reducing bacteria. Geochimica et Cosmochimica Acta 65, 1117-1124.

Canfield, D.E., 2001. Biogeochemistry of Sulfur Isotopes. Reviews in Mineralogy and Geochemistry 43, 607 -636. doi:10.2138/gsrmg.43.1.607

Canfield, D.E., 1998. A new model for Proterozoic ocean chemistry. Nature 396, 450453. doi:10.1038/24839

Canfield, D.E., Farquhar, J., Zerkle, A.L., 2010. High isotope fractionations during sulfate reduction in a low-sulfate euxinic ocean analog. Geology 38, 415-418.

Canfield, D.E., Poulton, S.W., Narbonne, G.M., 2007. Late-Neoproterozoic Deep-Ocean Oxygenation and the Rise of Animal Life. Science 315, 92 -95. doi:10.1126/science.1135013

Canfield, D.E., Raiswell, R., Westrich, J.T., Reaves, C.M., Berner, R.A., 1986. The use of chromium reduction in the analysis of reduced inorganic sulfur in sediments and shales. Chemical Geology 54, 149-155. doi:10.1016/00092541(86)90078-1

Canfield, D.E., Teske, A., 1996. Late Proterozoic rise in atmospheric oxygen concentration inferred from phylogenetic and sulphur-isotope studies. Nature 382, 127-132. doi:10.1038/382127a0

Canfield, D.E., Thamdrup, B., 1994. The production of 34S-depleted sulfide during bacterial disproportionation of elemental sulfur. Science 266, 1973-1975. doi: $10.1126 /$ science. 11540246

Chen, X., Ling, H.-F., Vance, D., Shields-Zhou, G.A., Zhu, M., Poulton, S.W., Och, L.M., Jiang, S.-Y., Li, D., Cremonese, L., Archer, C., 2015. Rise to modern levels of ocean oxygenation coincided with the Cambrian radiation of animals. Nat Commun 6. doi:10.1038/ncomms8142

Chen, Y., Chu, X., Zhang, X., Zhai, M., 2015. Carbon isotopes, sulfur isotopes, and trace elements of the dolomites from the Dengying Formation in Zhenba area, southern Shaanxi: Implications for shallow water redox conditions during the terminal Ediacaran. Sci. China Earth Sci. 58, 1107-1122.

doi:10.1007/s11430-015-5071-0

Claypool, G.E., Holser, W.T., Kaplan, I.R., Sakai, H., Zak, I., 1980. The age curves of sulfur and oxygen isotopes in marine sulfate and their mutual interpretation. Chemical Geology 28, 199-260. doi:10.1016/0009-2541(80)90047-9 
Condon, D., Zhu, M., Bowring, S., Wang, W., Yang, A., Jin, Y., 2005. U-Pb Ages from the Neoproterozoic Doushantuo Formation, China. Science 308, 95-98. doi:10.1126/science.1107765

Corsetti, F.A., Kaufman, A.J., 2003. Stratigraphic investigations of carbon isotope anomalies and Neoproterozoic ice ages in Death Valley, California. Geological Society of America Bulletin 115, 916-932.

Crowe, S.A., Paris, G., Katsev, S., Jones, C., Kim, S.-T., Zerkle, A.L., Nomosatryo, S., Fowle, D.A., Adkins, J.F., Sessions, A.L., Farquhar, J., Canfield, D.E., 2014.

Sulfate was a trace constituent of Archean seawater. Science 346, 735-739. doi:10.1126/science.1258966

Cui, H., Kaufman, A.J., Xiao, S., Peek, S., Cao, H., Min, X., Cai, Y., Siegel, Z., Liu, X.-M., Peng, Y., Schiffbauer, J.D., Martin, A.J., 2016. Environmental context for the terminal Ediacaran biomineralization of animals. Geobiology. doi:10.1111/gbi.12178

Derry, L.A., 2010. A burial diagenesis origin for the Ediacaran Shuram-Wonoka carbon isotope anomaly. Earth and Planetary Science Letters 294, 152-162.

Detmers, J., Bruchert, V., Habicht, K.S., Kuever, J., 2001. Diversity of sulfur isotope fractionations by sulfate-reducing prokaryotes. Applied and Environmental Microbiology 67, 888-894.

Ferrini, V., Fayek, M., De Vito, C., Mignardi, S., Pignatti, J., 2010. Extreme sulphur isotope fractionation in the deep Cretaceous biosphere. Journal of the Geological Society 167, 1009-1018.

Fike, D.A., Bradley, A.S., Rose, C.V., 2015. Rethinking the Ancient Sulfur Cycle. Annual Review of Earth and Planetary Sciences 43, 593-622. doi:10.1146/annurevearth-060313-054802

Fike, D.A., Finke, N., Zha, J., Blake, G., Hoehler, T.M., Orphan, V.J., 2009. The effect of sulfate concentration on (sub)millimeter-scale sulfide $\delta 34 \mathrm{~S}$ in hypersaline cyanobacterial mats over the diurnal cycle. Geochimica et Cosmochimica Acta 73, 6187-6204. doi:10.1016/j.gca.2009.07.006

Fike, D.A., Gammon, C.L., Ziebis, W., Orphan, V.J., 2008. Micron-scale mapping of sulfur cycling across the oxycline of a cyanobacterial mat: a paired nanoSIMS and CARD-FISH approach. ISME J 2, 749-759. doi:10.1038/ismej.2008.39

Fike, D.A., Grotzinger, J.P., 2008. A paired sulfate-pyrite $\delta 34 S$ approach to understanding the evolution of the Ediacaran-Cambrian sulfur cycle. Geochimica et Cosmochimica Acta 72, 2636-2648. doi:10.1016/j.gca.2008.03.021

Fike, D.A., Grotzinger, J.P., Pratt, L.M., Summons, R.E., 2006. Oxidation of the Ediacaran Ocean. Nature 444, 744-747. doi:10.1038/nature05345

Fry, B., Ruf, W., Gest, H., Hayes, J., 1988. Sulfur isotope effects associated with oxidation of sulfide by $\mathrm{O}_{2}$ in aqueous solution. Chemical Geology: Isotope Geoscience Section 73, 205-210.

Garrels, R.M., Lerman, A., 1981. Phanerozoic cycles of sedimentary carbon and sulfur. PNAS 78, 4652-4656.

Gellatly, A.M., Lyons, T.W., 2005. Trace sulfate in mid-Proterozoic carbonates and the sulfur isotope record of biospheric evolution. Geochimica et Cosmochimica Acta 69, 3813-3829. doi:10.1016/j.gca.2005.01.019 
Germs, G.J.B., 1974. The Nama Group in South West Africa and Its Relationship to the Pan-African Geosyncline. The Journal of Geology 82, 301-317.

Gill, B.C., Lyons, T.W., Frank, T.D., 2008. Behavior of carbonate-associated sulfate during meteoric diagenesis and implications for the sulfur isotope paleoproxy. Geochimica et Cosmochimica Acta 72, 4699-4711. doi:10.1016/j.gca.2008.07.001

Gomes, M.L., Hurtgen, M.T., 2013. Sulfur isotope systematics of a euxinic, low-sulfate lake: Evaluating the importance of the reservoir effect in modern and ancient oceans. Geology 41, 663-666. doi:10.1130/G34187.1

Goodfellow, W.D., Jonasson, I.R., 1984. Ocean stagnation and ventilation defined by $\delta 34 \mathrm{~S}$ secular trends in pyrite and barite, Selwyn Basin, Yukon. Geology 12, 583-586.

Grant, S.W., 1990. Shell structure and distribution of Cloudina, a potential index fossil for the terminal Proterozoic. Am J Sci 290-A, 261-294.

Grotzinger, J.P., Bowring, S.A., Saylor, B.Z., Kaufman, A.J., 1995. Biostratigraphic and Geochronologic Constraints on Early Animal Evolution. Science 270, 598 604. doi:10.1126/science.270.5236.598

Grotzinger, J.P., Fike, D.A., Fischer, W.W., 2011. Enigmatic origin of the largestknown carbon isotope excursion in Earth's history. Nature Geoscience 4, 285-292.

Grotzinger, J.P., Watters, W.A., Knoll, A.H., 2000. Calcified metazoans in thrombolitestromatolite reefs of the terminal Proterozoic Nama Group, Namibia.

Paleobiology 26, 334 -359. doi:10.1666/0094-

8373(2000)026<0334:CMITSR>2.0.CO;2

Habicht, K.S., Canfield, D.E., 2001. Isotope fractionation by sulfate-reducing natural populations and the isotopic composition of sulfide in marine sediments. Geology 29, 555 -558. doi:10.1130/00917613(2001)029<0555:IFBSRN>2.0.CO;2

Habicht, K.S., Gade, M., Thamdrup, B., Berg, P., Canfield, D.E., 2002. Calibration of Sulfate Levels in the Archean Ocean. Science 298, 2372-2374. doi:10.1126/science.1078265

Habicht, K.S., Salling, L., Thamdrup, B., Canfield, D.E., 2005. Effect of low sulfate concentrations on lactate oxidation and isotope fractionation during sulfate reduction by Archaeoglobus fulgidus strain Z. Applied and environmental microbiology 71, 3770-3777.

Hall, M., Kaufman, A.J., Vickers-Rich, P., Ivantsov, A., Trusler, P., Linnemann, U., Hofmann, M., Elliott, D., Cui, H., Fedonkin, M., others, 2013. Stratigraphy, palaeontology and geochemistry of the late Neoproterozoic Aar Member, southwest Namibia: Reflecting environmental controls on Ediacara fossil preservation during the terminal Proterozoic in African Gondwana. Precambrian Research 238, 214-232.

Hardie, L.A., 2003. Secular variations in Precambrian seawater chemistry and the timing of Precambrian aragonite seas and calcite seas. Geology 31, 785 -788. doi:10.1130/G19657.1

Hardie, L.A., 1996. Secular variation in seawater chemistry: An explanation for the coupled secular variation in the mineralogies of marine limestones and 
potash evaporites over the past 600 m.y. Geology 24, $279-283$.

doi:10.1130/0091-7613(1996)024<0279:SVISCA>2.3.C0;2

Holser, W.T., 1977. Catastrophic chemical events in the history of the ocean. Nature.

Hough, M.L., Shields, G.A., Evins, L.Z., Strauss, H., Henderson, R.A., Mackenzie, S., 2006. A major sulphur isotope event at c. 510 Ma: a possible anoxiaextinction-volcanism connection during the Early-Middle Cambrian transition? Terra Nova 18, 257-263. doi:10.1111/j.1365-3121.2006.00687.x

Houghton, M.L., 1980. Geochemistry of the Proterozoic Hormuz Evaporites, Southern Iran. University of Oregon.

Hurtgen, M.T., Halverson, G.P., Arthur, M.A., Hoffman, P.F., 2006. Sulfur cycling in the aftermath of a 635-Ma snowball glaciation: Evidence for a syn-glacial sulfidic deep ocean. Earth and Planetary Science Letters 245, 551-570. doi:10.1016/j.epsl.2006.03.026

Husson, J.M., Higgins, J.A., Maloof, A.C., Schoene, B., 2015. Ca and Mg isotope constraints on the origin of Earth's deepest $C$ excursion. Geochimica et Cosmochimica Acta 160, 243-266. doi:10.1016/j.gca.2015.03.012

Johnston, D., Gill, B., Masterson, A., Beirne, E., Casciotti, K., Knapp, A., Berelson, W., 2014. Placing an upper limit on cryptic marine sulphur cycling. Nature 513.7519, 530-533.

Kah, L.C., Lyons, T.W., Frank, T.D., 2004. Low marine sulphate and protracted oxygenation of the Proterozoic biosphere. Nature 431, 834-838. doi: $10.1038 /$ nature 02974

Kampschulte, A., Strauss, H., 2004. The sulfur isotopic evolution of Phanerozoic seawater based on the analysis of structurally substituted sulfate in carbonates. Chemical Geology 204, 255-286. doi:10.1016/j.chemgeo.2003.11.013

Kaplan, I.R., Rittenberg, S.C., 1964. Microbiological Fractionation of Sulphur Isotopes. J Gen Microbiol 34, 195-212. doi:10.1099/00221287-34-2-195

Kaufman, A.J., Hayes, J., Knoll, A.H., Germs, G.J., 1991. Isotopic compositions of carbonates and organic carbon from upper Proterozoic successions in Namibia: stratigraphic variation and the effects of diagenesis and metamorphism. Precambrian Research 49, 301-327.

Knauth, L.P., Kennedy, M.J., 2009. The late Precambrian greening of the Earth.

Knoll, A.H., 2014. Paleobiological Perspectives on Early Eukaryotic Evolution. Cold Spring Harb Perspect Biol 6, a016121. doi:10.1101/cshperspect.a016121

Knoll, A.H., Sperling, E.A., 2014. Oxygen and animals in Earth history. Proceedings of the National Academy of Sciences 111, 3907-3908.

Knossow, N., Blonder, B., Eckert, W., Turchyn, A.V., Antler, G., Kamyshny, A., 2015. Annual sulfur cycle in a warm monomictic lake with sub-millimolar sulfate concentrations. Geochemical Transactions 16. doi:10.1186/s12932-0150021-5

Kovalevych, V.M., Marshall, T., Peryt, T.M., Petrychenko, O.Y., Zhukova, S.A., 2006. Chemical composition of seawater in Neoproterozoic: Results of fluid inclusion study of halite from Salt Range (Pakistan) and Amadeus Basin (Australia). Precambrian Research 144, 39-51. doi:10.1016/j.precamres.2005.10.004 
Leavitt, W.D., Halevy, I., Bradley, A.S., Johnston, D.T., 2013. Influence of sulfate reduction rates on the Phanerozoic sulfur isotope record. PNAS. doi: $10.1073 /$ pnas. 1218874110

Le Guerroué, E., 2010. Duration and synchroneity of the largest negative carbon isotope excursion on Earth: The Shuram/Wonoka anomaly. Comptes Rendus Geoscience 342, 204-214. doi:10.1016/j.crte.2009.12.008

Li, C., Love, G.D., Lyons, T.W., Fike, D.A., Sessions, A.L., Chu, X., 2010. A stratified redox model for the Ediacaran ocean. Science 328, 80-83. doi:10.1126/science.1182369

Ling, H.-F., Chen, X., Li, D., Wang, D., Shields-Zhou, G.A., Zhu, M., 2013. Cerium anomaly variations in Ediacaran-earliest Cambrian carbonates from the Yangtze Gorges area, South China: implications for oxygenation of coeval shallow seawater. Precambrian Research 225, 110-127.

Liu, T.-B., Maynard, J.B., Alten, J., 2006. Superheavy S isotopes from glacierassociated sediments of the Neoproterozoic of south China: Oceanic anoxia or sulfate limitation? Geological Society of America Memoirs 198, 205-222.

Loyd, S.J., Marenco, P.J., Hagadorn, J.W., Lyons, T.W., Kaufman, A.J., Sour-Tovar, F., Corsetti, F.A., 2012. Sustained low marine sulfate concentrations from the Neoproterozoic to the Cambrian: Insights from carbonates of northwestern Mexico and eastern California. Earth and Planetary Science Letters 339, 7994.

Lu, M., Zhu, M., Zhang, J., Shields-Zhou, G., Li, G., Zhao, F., Zhao, X., Zhao, M., 2013. The DOUNCE event at the top of the Ediacaran Doushantuo Formation, South China: Broad stratigraphic occurrence and non-diagenetic origin. Precambrian Research, Biogeochemical changes across the EdiacaranCambrian transition in South China 225, 86-109. doi:10.1016/j.precamres.2011.10.018

Lyons, T.W., Walter, L.M., Gellatly, A.M., Martini, A.M., Blake, R.E., 2004. Sites of anomalous organic remineralization in the carbonate sediments of South Florida, USA: the sulfur cycle and carbonate-associated sulfate. Geological Society of America Special Papers 379, 161-176.

Macdonald, F.A., Pruss, S.B., Strauss, J.V., 2014. Trace fossils with spreiten from the late Ediacaran Nama Group,Namibia: complex feeding patterns five million years before the Precambrian-Cambrian boundary. Journal of Paleontology 88, 299-308.

Macdonald, F.A., Strauss, J.V., Sperling, E.A., Halverson, G.P., Narbonne, G.M., Johnston, D.T., Kunzmann, M., Schrag, D.P., Higgins, J.A., 2013. The stratigraphic relationship between the Shuram carbon isotope excursion, the oxygenation of Neoproterozoic oceans, and the first appearance of the Ediacara biota and bilaterian trace fossils in northwestern Canada. Chemical Geology, Special Issue dedicated to H.D. Holland: Evolution of the atmosphere and ocean through time 362, 250-272. doi:10.1016/j.chemgeo.2013.05.032

Marenco, P.J., Corsetti, F.A., Hammond, D.E., Kaufman, A.J., Bottjer, D.J., 2008. Oxidation of pyrite during extraction of carbonate associated sulfate. Chemical Geology 247, 124-132. 
Markovic, S., Paytan, A., Wortmann, U.G., 2015. Pleistocene sediment offloading and the global sulfur cycle. Biogeosciences Discussions 12, 1205-1245.

doi:10.5194/bgd-12-1205-2015

Mattes, B.W., Morris, S.C., 1990. Carbonate/evaporite deposition in the Late Precambrian - Early Cambrian Ara Formation of Southern Oman. Geological Society, London, Special Publications 49, 617-636.

doi:10.1144/GSL.SP.1992.049.01.37

McFadden, K.A., Huang, J., Chu, X., Jiang, G., Kaufman, A.J., Zhou, C., Yuan, X., Xiao, S., 2008. Pulsed oxidation and biological evolution in the Ediacaran Doushantuo Formation. Proceedings of the National Academy of Sciences 105, 31973202.

Mcllroy, D., Logan, G.A., 1999. The impact of bioturbation on infaunal ecology and evolution during the Proterozoic-Cambrian transition. Palaios 14, 58-72.

Miller, R.M., 1983. The Pan-African Damara Orogen of South West Africa/Namibia.

Moles, N.R., Boyce, A.J., Fallick, A.E., 2015. Abundant sulphate in the Neoproterozoic ocean: implications of constant $\delta 34 \mathrm{~S}$ of barite in the Aberfeldy SEDEX deposits, Scottish Dalradian. Geological Society, London, Special Publications 393, 189-212. doi:10.1144/SP393.7

Morris, S.C., Mattes, B., Chen, M., 1990. The early skeletal organism Cloudina: new occurrences from Oman and possibly China. American Journal of Science 245-260.

Och, L.M., Cremonese, L., Shields-Zhou, G.A., Poulton, S.W., Struck, U., Ling, H., Li, D., Chen, X., Manning, C., Thirlwall, M., Strauss, H., Zhu, M., 2016.

Palaeoceanographic controls on spatial redox distribution over the Yangtze Platform during the Ediacaran-Cambrian transition. Sedimentology 63, 378410. doi:10.1111/sed.12220

Och, L.M., Shields-Zhou, G.A., 2012. The Neoproterozoic oxygenation event: environmental perturbations and biogeochemical cycling. Earth-Science Reviews 110, 26-57.

Paytan, A., Kastner, M., Campbell, D., Thiemens, M.H., 2004. Seawater Sulfur Isotope Fluctuations in the Cretaceous. Science 304, 1663-1665. doi:10.1126/science.1095258

Paytan, A., Kastner, M., Campbell, D., Thiemens, M.H., 1998. Sulfur Isotopic Composition of Cenozoic Seawater Sulfate. Science 282, 1459-1462. doi:10.1126/science.282.5393.1459

Peng, Y., Bao, H., Pratt, L.M., Kaufman, A.J., Jiang, G., Boyd, D., Wang, Q., Zhou, C., Yuan, X., Xiao, S., Loyd, S., 2014. Widespread contamination of carbonate-associated sulfate by present-day secondary atmospheric sulfate: Evidence from triple oxygen isotopes. Geology 42, 815-818.

Penny, A.M., Wood, R.A., Zhuravlev, A.Y., Curtis, A., Bowyer, F., Tostevin, R., 2016. Intraspecific variation in an Ediacaran skeletal metazoan: Namacalathus from the Nama Group, Namibia. Geobiology. doi:10.1111/gbi.12205

Penny, A., Wood, R., Curtis, A., Bowyer, F., Tostevin, R., Hoffman, K.-H., 2014. Ediacaran metazoan reefs from the Nama Group, Namibia. Science 344, 1504-1506. 
Present, T.M., Paris, G., Burke, A., Fischer, W.W., Adkins, J.F., 2015. Large Carbonate Associated Sulfate isotopic variability between brachiopods, micrite, and other sedimentary components in Late Ordovician strata. Earth and Planetary Science Letters 432, 187-198. doi:10.1016/j.epsl.2015.10.005

Raab, M., Spiro, B., 1991. Sulfur isotopic variations during seawater evaporation with fractional crystallization. Chemical Geology: Isotope Geoscience section 86, 323-333. doi:10.1016/0168-9622(91)90014-N

Rees, C.E., 1978. Sulphur isotope measurements using SO2 and SF6. Geochimica et Cosmochimica Acta 42, 383-389. doi:10.1016/0016-7037(78)90269-7

Rees, C.E., 1973. A steady-state model for sulphur isotope fractionation in bacterial reduction processes. Geochimica et Cosmochimica Acta 37, 1141-1162. doi:10.1016/0016-7037(73)90052-5

Rennie, V.C.F., Turchyn, A.V., 2014. The preservation of and in carbonate-associated sulfate during marine diagenesis: A 25 Myr test case using marine sediments. Earth and Planetary Science Letters 395, 13-23. doi:10.1016/j.epsl.2014.03.025

Ries, J.B., Fike, D.A., Pratt, L.M., Lyons, T.W., Grotzinger, J.P., 2009. Superheavy pyrite ( $\delta 34$ Spyr $>\delta 34$ SCAS) in the terminal Proterozoic Nama Group, southern Namibia: A consequence of low seawater sulfate at the dawn of animal life. Geology 37, 743 -746. doi:10.1130/G25775A.1

Rothman, D.H., Hayes, J.M., Summons, R.E., 2003. Dynamics of the Neoproterozoic carbon cycle. PNAS 100, 8124-8129. doi:10.1073/pnas.0832439100

Runnegar, B., 1982. Oxygen requirements, biology and phylogenetic significance of the late Precambrian worm Dickinsonia, and the evolution of the burrowing habit. Alcheringa: An Australasian Journal of Palaeontology 6, 223-239. doi:10.1080/03115518208565415

Sahoo, S.K., Planavsky, N.J., Jiang, G., Kendall, B., Owens, J.D., Wang, X., Shi, X., Anbar, A.D., Lyons, T.W., 2016. Oceanic oxygenation events in the anoxic Ediacaran ocean. Geobiology n/a-n/a. doi:10.1111/gbi.12182

Saylor, B.Z., Kaufman, A.J., Grotzinger, J.P., Urban, F., 1998. A Composite Reference Section for Terminal Proterozoic Strata of Southern Namibia. SEPM Journal of Sedimentary Research 68. doi:10.1306/D426893C-2B26-11D78648000102C1865D

Schmitz, M.D., 2012. Radiogenic isotope geochronology. Geologic Time Scale 115126.

Schrag, D.P., Higgins, J.A., Macdonald, F.A., Johnston, D.T., 2013. Authigenic carbonate and the history of the global carbon cycle. science 339, 540-543.

Schröder, S., Grotzinger, J. p., 2007. Evidence for anoxia at the Ediacaran-Cambrian boundary: the record of redox-sensitive trace elements and rare earth elements in Oman. Journal of the Geological Society 164, 175-187. doi:10.1144/0016-76492005-022

Schröder, S., Grotzinger, J.P., Amthor, J.E., Matter, A., 2005. Carbonate deposition and hydrocarbon reservoir development at the Precambrian-Cambrian boundary: The Ara Group in South Oman. Sedimentary Geology 180, 1-28. doi:10.1016/j.sedgeo.2005.07.002 
Schröder, S., Schreiber, B.C., Amthor, J.E., Matter, A., 2003. A depositional model for the terminal Neoproterozoic-Early Cambrian Ara Group evaporites in south Oman. Sedimentology 50, 879-898. doi:10.1046/j.1365-3091.2003.00587.x

Schroder, S., Schreiber, C., Amthor, J.E., Matter, A., 2004. Stratigraphy and environmental conditons of the terminal Neoproterozoic - Cambrian period in Oman: evidence from sulphur isotopes. Journal of the Geological Society 161, 489-499.

Shen, Y., Zhang, T., Hoffman, P.F., 2008. On the coevolution of Ediacaran oceans and animals. Proceedings of the National Academy of Sciences 105, 7376-7381.

Shields, G.A., Deynoux, M., Strauss, H., Paquet, H., Nahon, D., 2007. Barite-bearing cap dolostones of the Taoudéni Basin, northwest Africa: Sedimentary and isotopic evidence for methane seepage after a Neoproterozoic glaciation. Precambrian Research 153, 209-235. doi:10.1016/j.precamres.2006.11.011

Shields, G.A., Strauss, H., Howe, S.S., Siegmund, H., 1999. Sulphur isotope compositions of sedimentary phosphorites from the basal Cambrian of China: implications for Neoproterozoic-Cambrian biogeochemical cycling. Journal of the Geological Society 156, 943-955.

Shields, G., Kimura, H., Yang, J., Gammon, P., 2004. Sulphur isotopic evolution of Neoproterozoic-Cambrian seawater: new francolite-bound sulphate $\$ \backslash$ delta^$^{\wedge} 34$ S data and a critical appraisal of the existing record. Chemical Geology 204, 163-182.

Sim, M.S., Bosak, T., Ono, S., 2011a. Large Sulfur Isotope Fractionation Does Not Require Disproportionation. Science 333, 74-77. doi:10.1126/science.1205103

Sim, M.S., Ono, S., Donovan, K., Templer, S.P., Bosak, T., 2011b. Effect of electron donors on the fractionation of sulfur isotopes by a marine Desulfovibrio sp. Geochimica et Cosmochimica Acta 75, 4244-4259. doi:10.1016/j.gca.2011.05.021

Solomon, M., Rafter, T.A., Dunham, K.C., 1971. Sulphur and oxygen isotope studies in the northern Pennines in relation to ore diagenesis. Transactions of the Institution of Mining and Metallurgy 259-275.

Sperling, E.A., Wolock, C.J., Morgan, A.S., Gill, B.C., Kunzmann, M., Halverson, G.P., Macdonald, F.A., Knoll, A.H., Johnston, D.T., 2015. Statistical analysis of iron geochemical data suggests limited late Proterozoic oxygenation. Nature 523, 451-454. doi:10.1038/nature14589

Staudt, W.J., Schoonen, M.A., 1995. Sulfate incorporation into sedimentary carbonates, in: ACS Symposium Series. Washington, DC: American Chemical Society,[1974], pp. 332-347.

Strauss, H., 1997. The isotopic composition of sedimentary sulfur through time. Palaeogeography, Palaeoclimatology, Palaeoecology 132, 97-118. doi:10.1016/S0031-0182(97)00067-9

Strauss, H., Banerjee, D.M., Kumar, V., 2001. The sulfur isotopic composition of Neoproterozoic to early Cambrian seawater-evidence from the cyclic Hanseran evaporites, NW India. Chemical Geology 175, 17-28. 
Strauss, H., Bengtson, S., Myrow, P.M., Vidal, G., 1992. Stable isotope geochemistry and palynology of the late Precambrian to Early Cambrian sequence in Newfoundland. Canadian Journal of Earth Sciences 29, 1662-1673.

Swart, P.K., Kennedy, M.J., 2012. Does the global stratigraphic reproducibility of $\delta 13 \mathrm{C}$ in Neoproterozoic carbonates require a marine origin? A PliocenePleistocene comparison. Geology 40, 87-90. doi:10.1130/G32538.1

Theiling, B.P., Coleman, M., 2015. Refining the extraction methodology of carbonate associated sulfate: Evidence from synthetic and natural carbonate samples. Chemical Geology 411, 36-48. doi:10.1016/j.chemgeo.2015.06.018

Thode, H., Monster, J., 1965. Sulfur-isotope geochemistry of petroleum, evaporites, and ancient seas, in: Fluids in Subsurfaces Environments: A Symposium, Memoir No. 4. American Association of Petroleum Geologists, 1965. AAPG Special Volumes, pp. 367-377.

Thode, H.., Monster, J., Dunford, H.., 1961. Sulphur isotope geochemistry. Geochimica et Cosmochimica Acta 25, 159-174. doi:10.1016/0016-7037(61)90074-6

Tostevin, R., Wood, R.A., Shields, G.A., Poulton, S.W., Guilbaud, R., Bowyer, F., Penny, A.M., He, T., Curtis, A., Hoffmann, K.H., Clarkson, M.O., 2016. Low-oxygen waters limited habitable space for early animals. Nature Communications 7. doi:10.1038/ncomms12818

Towe, K.M., 1970. Oxygen-Collagen Priority and the Early Metazoan Fossil Record. PNAS 65, 781-788.

Turchyn, A.V., Schrag, D.P., Coccioni, R., Montanari, A., 2009. Stable isotope analysis of the Cretaceous sulfur cycle. Earth and Planetary Science Letters 285, 115123. doi:10.1016/j.epsl.2009.06.002

Wang, J., Chen, D., Yan, D., Wei, H., Xiang, L., 2012. Evolution from an anoxic to oxic deep ocean during the Ediacaran-Cambrian transition and implications for bioradiation. Chemical Geology 306-307, 129-138. doi:10.1016/j.chemgeo.2012.03.005

Weber, H.S., Thamdrup, B., Habicht, K.S., 2016. High Sulfur Isotope Fractionation Associated with Anaerobic Oxidation of Methane in a Low-Sulfate, Iron-Rich Environment. Front. Earth Sci 61. doi:10.3389/feart.2016.00061

Wilbanks, E.G., Jaekel, U., Salman, V., Humphrey, P.T., Eisen, J.A., Facciotti, M.T., Buckley, D.H., Zinder, S.H., Druschel, G.K., Fike, D.A., Orphan, V.J., 2014. Microscale sulfur cycling in the phototrophic pink berry consortia of the Sippewissett Salt Marsh. Environ Microbiol 16, 3398-3415. doi:10.1111/1462-2920.12388

Wood, R.A., Grotzinger, J.P., Dickson, J.A.D., 2002. Proterozoic Modular Biomineralized Metazoan from the Nama Group, Namibia. Science 296, 2383 -2386. doi:10.1126/science.1071599

Wood, R.A., Poulton, S.W., Prave, A.R., Hoffmann, K.-H., Clarkson, M.O., Guilbaud, R., Lyne, J.W., Tostevin, R., Bowyer, F., Penny, A.M., Curtis, A., Kasemann, S.A., 2015. Dynamic redox conditions control late Ediacaran ecosystems in the Nama Group, Namibia. Precambrian Research 261, 252-271.

Wortmann, U.G., Bernasconi, S.M., Böttcher, M.E., 2001. Hypersulfidic deep biosphere indicates extreme sulfur isotope fractionation during single-step microbial sulfate reduction. Geology 29, 647-650. 
Wotte, T., Shields-Zhou, G.A., Strauss, H., 2012. Carbonate-associated sulfate: experimental comparisons of common extraction methods and recommendations toward a standard analytical protocol. Chemical Geology 326, 132-144.

Wu, N., Farquhar, J., Fike, D.A., 2015. Ediacaran sulfur cycle: Insights from sulfur isotope measurements $(\Delta 33 \mathrm{~S}$ and $\delta 34 \mathrm{~S}$ ) on paired sulfate-pyrite in the Huqf Supergroup of Oman. Geochimica et Cosmochimica Acta.

Zhang, T., Chu, X., Zhang, Q., Feng, L., Huo, W., 2004. The sulfur and carbon isotopic records in carbonates of the Dengying Formation in the Yangtze Platform, China. Acta Petrologica Sinica 20, 717-724.

Zhang, T., Chu, X., Zhang, Q., Feng, L., Huo, W., 2003. Variations of sulfur and carbon isotopes in seawater during the Doushantuo stage in late Neoproterozoic. Chin.Sci.Bull. 48, 1375-1380. doi:10.1007/BF03184182

Zhuravlev, A.Y., Wood, R.A., 2008. Eve of biomineralization: Controls on skeletal mineralogy. Geology 36, 923 -926. doi:10.1130/G25094A.1 
Figure 1: Simplified geological map of Namibia, showing the location of Zebra River section in the Kuibis Subgroup of the Nama Group, modified from Miller, (1983).

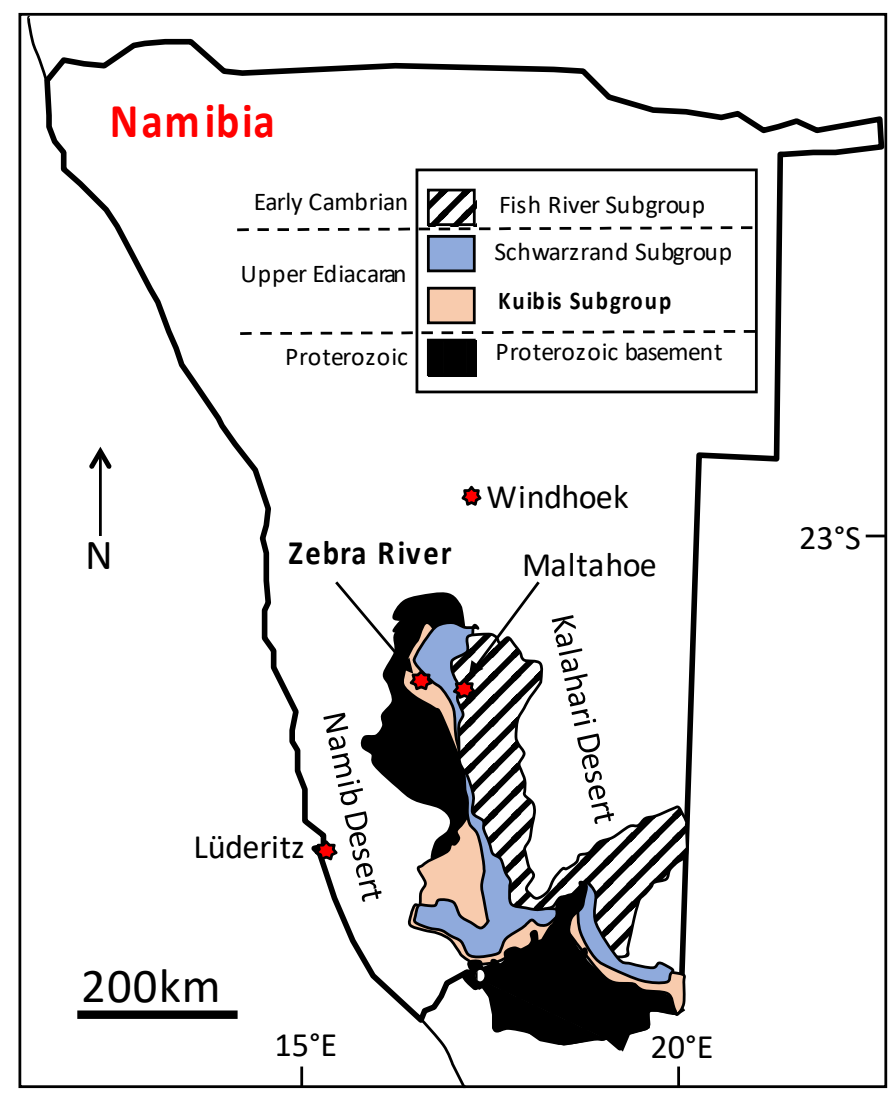


Figure 2: The first panel shows Carbon isotope ratios for Zebra River. In the second panel, $\delta^{34} S_{\text {CAS }}$ from this study is shown alongside $\delta^{34}$ pyr. The third panel shows the isotope composition of CAS minus pyrite, $\Delta^{34} \mathrm{~S}$ sw-pyr.The final panel shows sulfur isotope composition of CAS and pyrite from this study compared with equivelant parts of the stratigraphy from Ries et al. (2009). In the lower Omkyk, this study presents higher $\delta^{34} S_{s w}$ than Ries et al. (2009) (grey box). Data from Ries et al. (2009) have been replotted on an equivalent depth scale using member boundaries.
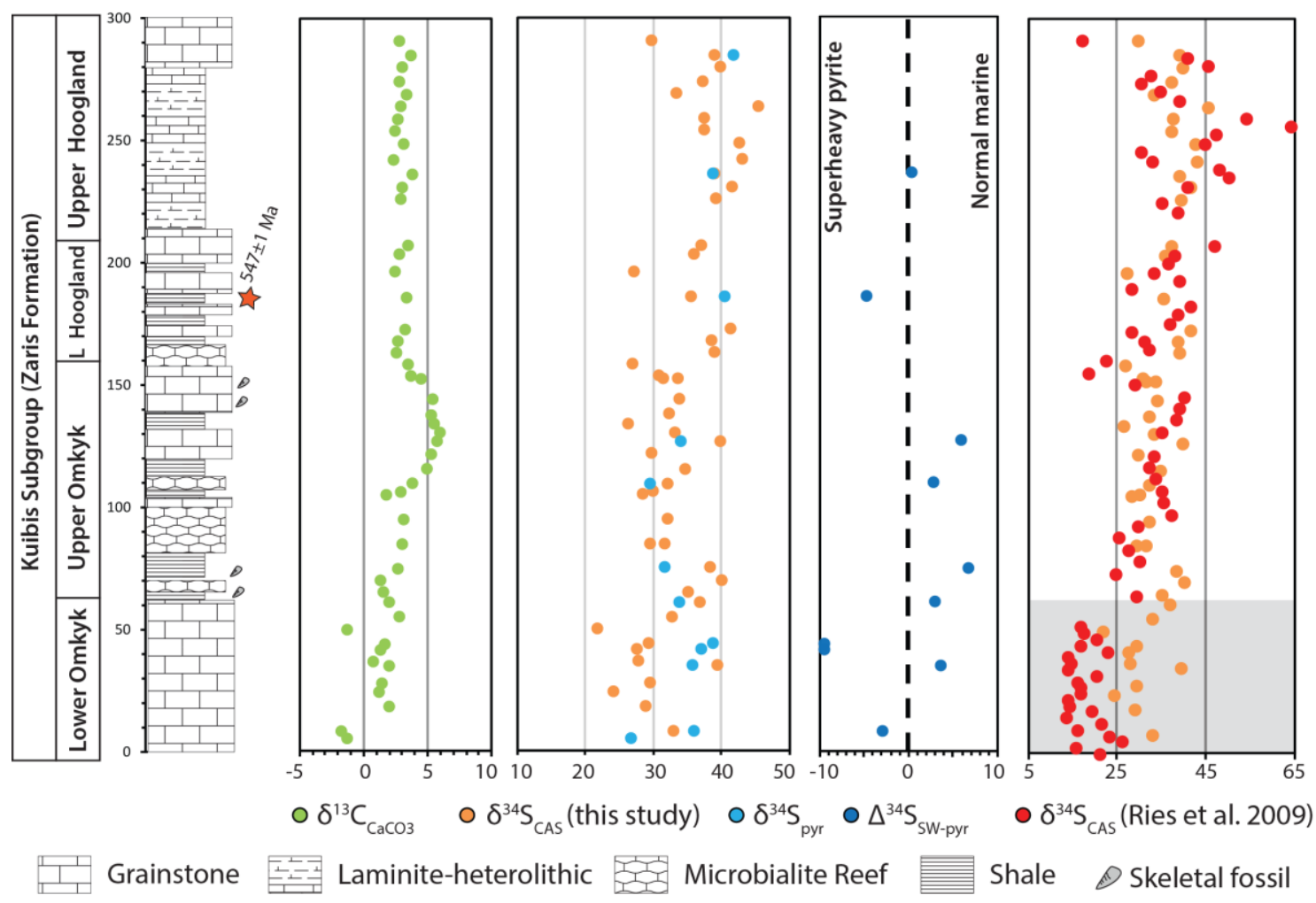

Shale Skeletal fossil 
Figure 3: $\delta^{34} \mathrm{~S}_{\mathrm{CAS}}$ shows no correlation with traditional indicators of diagenesis, CAS concentration, $\mathrm{Mn} / \mathrm{Sr}$ or $\delta^{18} \mathrm{~S}$ Сaco3. In addition, the $\delta^{34} \mathrm{~S}$ CAS does not appear to follow lithological trends or facies changes.
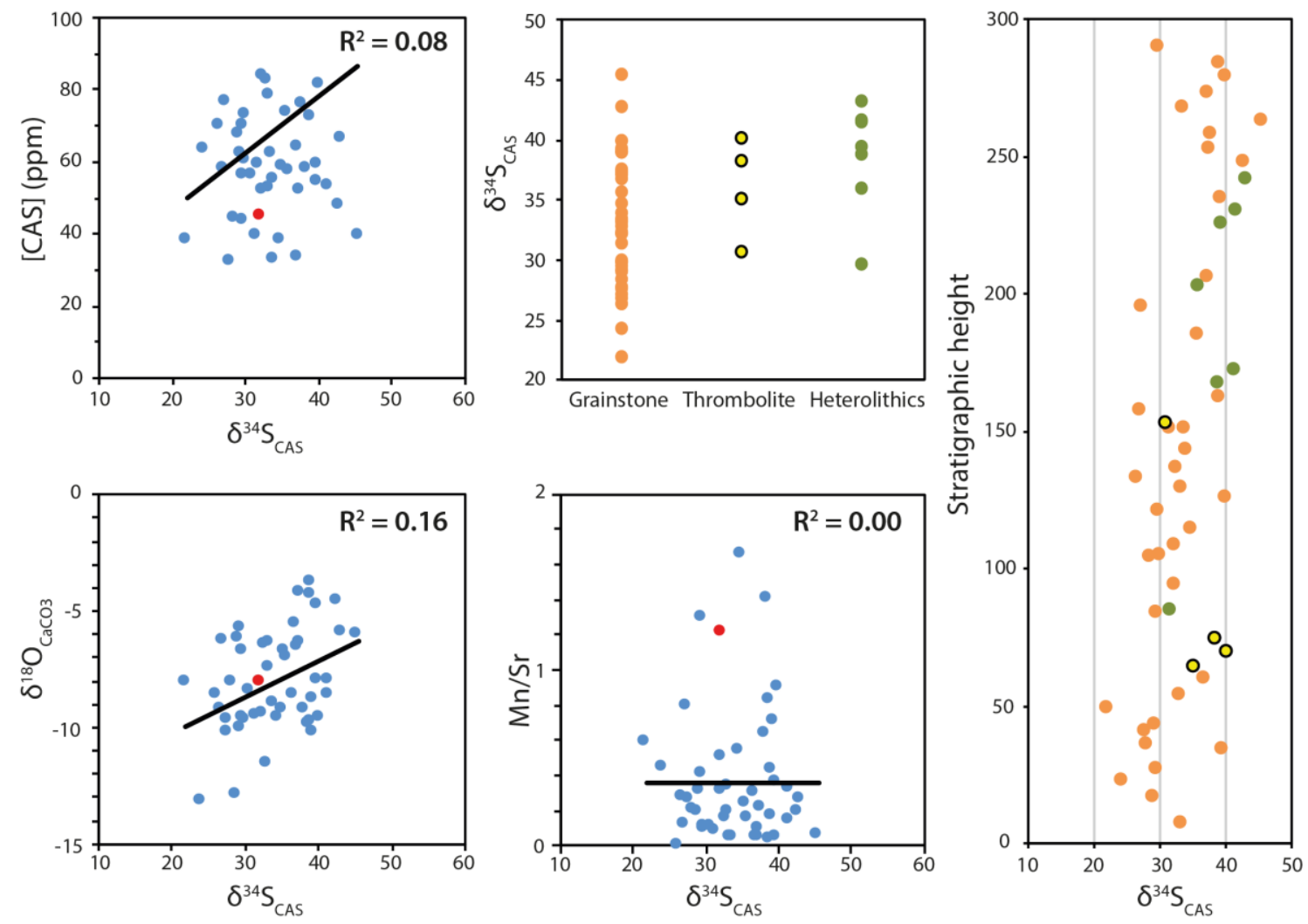

Limestone

Dolomite

Thrombolite
Heterolithics 
Figure 4: Comparison of $\delta^{34} \mathrm{~S}_{\mathrm{CAS}}$ and $\delta^{13} \mathrm{C}$ data from carbonate successions from the Buah Formation and Ara Group, Oman (Fike et al., 2006; Wu et al., 2015); the Gaojiashan Member, south China (Cui et al., 2016) and the Nama Group, Namibia (ths study). Radiometric age constraints and associated uncertainties are shown. Potential tie points betweent Oman and the Nama Group (TP1-3) are referred to in the text when discussing correlations between $\mathrm{C}$ and $\mathrm{S}$ isotope records.

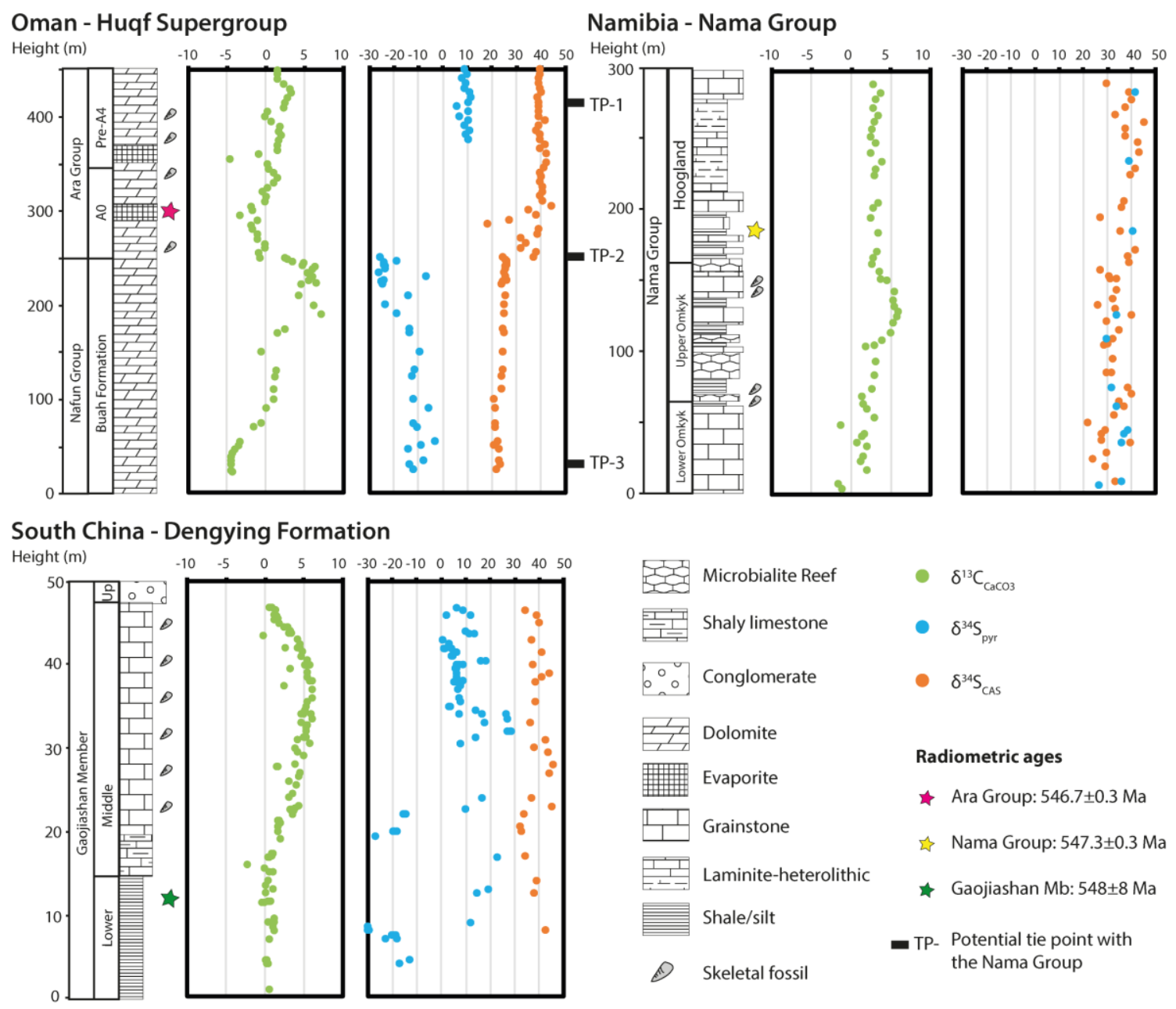


Table 1: Average sulfur isotope composition of CAS and pyrite in each member from this study and Ries et al. (2009), where ' $n$ ' indicates the number of analyses. Errors are one standard deviation. In the lower Omkyk, this study presents higher $\delta^{34} S$ than Ries et al. (2009).

\begin{tabular}{|c|c|c|c|c|}
\hline Member & Study & $\delta^{34} \mathrm{~S}$ CAS & $\delta^{34}$ S Pyrite & $\begin{array}{l}\text { Pyrite compared } \\
\text { with CAS }\end{array}$ \\
\hline \multirow[t]{2}{*}{ Lower Omkyk } & This study & $\begin{array}{l}30.1 \pm 5.1 \% 0 \\
(n=11)\end{array}$ & $\begin{array}{l}36.3 \pm 1.8 \% 0 \\
(n=5)\end{array}$ & \multirow{2}{*}{$\begin{array}{l}\text { Some } \\
\text { 'superheavy' }\end{array}$} \\
\hline & Ries et al. 2009 & $17.7 \pm 3.6 \% 0$ & $28.7 \pm 4.0 \%$ & \\
\hline \multirow[t]{2}{*}{ Upper Omkyk } & This study & $\begin{array}{l}32.5 \pm 3.8 \% 0 \\
(n=20)\end{array}$ & $\begin{array}{l}31.7 \pm 2.2 \% 0 \\
(n=3)\end{array}$ & \multirow[t]{2}{*}{ Similar } \\
\hline & Ries et al. 2009 & $31.4 \pm 5.9 \% 0$ & $29.9 \pm 5.9 \%$ & \\
\hline \multirow[t]{2}{*}{ Hoogland } & This study & $\begin{array}{l}38.0 \pm 4.3 \% 0 \\
(n=20)\end{array}$ & $\begin{array}{l}40.4 \pm 1.5 \% 0 \\
(n=3)\end{array}$ & \multirow{2}{*}{$\begin{array}{l}\text { Some } \\
\text { 'superheavy' }\end{array}$} \\
\hline & Ries et al. 2009 & $38.6 \pm 9.1 \% 0$ & $40.9 \pm 12.7 \% 0$ & \\
\hline
\end{tabular}

Table 2: Sulfur isotope ratios, $\delta^{34} \mathrm{~S}$, of the first two sodium chloride leachates compared with CAS for three selected samples. Leaches 3-5 did not produce sufficient precipitate for isotopic analysis. Pre-leaches shows lower $\delta^{34} \mathrm{~S}$ compared with final CAS value, consistent with previous method development work by Wotte et al. (2012) and Peng et al., (2014). 


\begin{tabular}{|l|c|c|c|}
\hline Sample & $\boldsymbol{\delta}^{\mathbf{3 4}} \mathbf{S}-$ Leach 1 & $\boldsymbol{\delta}^{\mathbf{3 4}} \mathbf{S}-$ Leach 2 & $\boldsymbol{\delta}^{\mathbf{3 4}} \mathbf{S}-\mathbf{C A S}$ \\
\hline UH11 & 35.2 & 22.3 & 33.4 \\
\hline UH5 & 38.1 & 34.4 & 39.1 \\
\hline UH14 & 23.1 & - & 38.9 \\
\hline
\end{tabular}

